\title{
Functional foods: psychological and behavioural functions
}

\author{
Louise Dye* and John Blundell \\ School of Psychology, University of Leeds, Leeds LS2 9JT, UK
}

\begin{abstract}
It is easier to demonstrate the consistent effects of foods on satiety than on cognitive performance. This is understandable since the satiety system incorporates physiological signalling systems that mediate the effects of foods on function. Specific manipulations of proteins, carbohydrates and fats have the potential to act as functional foods for appetite control. Because of the importance of the optimal functioning of cognitions for survival, these functions are quite strongly protected against short-term dietary and physiological perturbances. Therefore, food manipulations may be better detected through the degree of effort exerted to maintain performance rather than via changes in the actual performance itself. This procedure has not been widely used hitherto. The concept of biomarkers may have to be interpreted differently from research on physiological systems or clinical endpoints. For satiety, adjustments in the profile of hunger could serve as a biomarker or surrogate endpoint. For cognitions, correlated physiological variables may be more difficult to measure than the functional endpoint itself. Changes related to unitary functions (such as tracking) could serve as biomarkers for more complex, integrated skills (such as car driving). Since food manipulations may affect multiple functions, the challenge is to design foods with good satiety control that do not impair mental performance; or alternatively to engineer foods that optimise cognitive performance without compromising satiety. This rapidly developing field has great potential for close collaboration between academia and industry in the production of commercially successful products that show clear improvements in human functioning with the capacity to protect against disease or impairment.
\end{abstract}

Satiety: Biomarker: Cognitive performance: Functional foods

\section{Introduction}

In the First International Conference on East-West Perspectives on Functional Foods, the major emphasis was on physiological and metabolic functions. Although much of this material was relevant for well-being and quality of life, there was almost no mention of the direct effects of foods on psychological functions involving the expression of behaviour (such as food intake or appetite) or the articulation of mental state (mood) or mental abilities (cognitive performance).

In the intervening period the world-wide epidemic of obesity has been recognised, thus bringing appetite control to the forefront of functions susceptible to modulation by foods and food ingredients. Consequently, functional foods for the control of appetite (and ultimately body weight) now constitute a major health goal and research objective. In addition, the principle that foods can reliably affect cognitive performance is receiving validation and experimental support. This domain of research is still in a relative state of infancy but also rapid development.
In these areas of research it is not clear that the concept of biomarkers has the same meaning as in other domains which relate physiological functions to some health endpoint or disease protection. However, it is possible to suggest ways in which biomarkers for complex psychological and behavioural functions could be identified.

This interim report has evolved from the International Life Science Institute's Functional Food Science in Europe (FUFOSE) Project and is designed to provide a perspective on the field and to indicate possibilities for future developments. The FUFOSE programme concentrated on the behavioural functions of appetite control, cognitive performance and mood, and this approach has been followed here.

\section{Functional foods for satiety}

The control of appetite

The ultimate objective of research in this area is to develop 
foods that will protect individuals from weight gain or bring about a weight loss. The first of these objectives will be the most readily attainable. This means that foods must prevent individuals from reaching a state of positive energy balance - this means ensuring that energy intake does not exceed energy expenditure. Although it is more readily recognised that foods should have the potential to control energy intake, it should be kept in mind that foods can also enhance energy expenditure either through metabolic activity (e.g. thermogenesis) or by increasing physical activity. It is important to recognise that behaviour accounts for $100 \%$ of energy intake and between 20 and $60 \%$ of energy expenditure. Therefore the direct effect of foods on behaviour is critical.

Considering the reduction of energy uptake, adjusting the composition of the diet is a valid proposition. The use of specific macronutrient manipulations can help to suppress hunger and reduce the amount of food eaten. Alternatively, specific materials can be incorporated into food (such as yoghurts) so as to produce an intense action on satiety-signalling systems. This strategy involves the development of functional foods (nutraceuticals) for appetite control. There is a huge opportunity for foods in this sector of the food market.

\section{Appetite control and the satiety cascade}

The biological drive to eat is linked to the satiating power of food. Satiating power, or satiating efficiency, describes the capacity of a food to suppress and to inhibit further eating. Food causes this effect by certain mediating processes that can be roughly classified as sensory, cognitive, post-ingestive (pre-absorptive) and post-absorptive. These processes are operated by the impact of food on physiological and biochemical mechanisms, and collectively these processes have been referred to as the satiety cascade. The way in which food is sensed and processed by the biological system generates neural and humoral signals, which are used to control appetite. It follows that any selfimposed or externally applied reduction in the food supply, creating a calorific deficit, will weaken the satiating power of food. One consequence of this will be the failure of food to suppress hunger adequately (the biological drive). The satiety cascade appears to operate as efficiently in obese people as in lean individuals - a normal appetite response to reduced calorie intake is evident in obese subjects.

Technically, satiety can be defined as inhibition of hunger and eating that arises as a consequence of food consumption. It can be distinguished from satiation, which is the process that brings a period of eating to a halt. Consequently, satiation and satiety act together to determine the pattern of eating behaviour and the accompanying profile of motivation. The conscious sensation of hunger is one index of motivation and reflects the strength of satiation and satiety. It is worth remembering that hunger is a biologically useful sensation. It is a nagging, irritating feeling that prompts thoughts of food and reminds us that the body needs energy. The identification and management of hunger are important factors underlying normal appetite function and abnormalities of appetite and body weight.

\section{Physiological satiety signals}

A key feature in understanding the effect of foods on satiety is the recognition of physiological satiety signals. Even before food touches the mouth, physiological signals are generated by the sight and smell of food. These events constitute the cephalic phase of appetite. Cephalic phase responses are generated in many parts of the gastrointestinal tract; their function is to anticipate the ingestion of food. During and immediately after eating, afferent information provides the major control over appetite. Afferent information from food in the mouth provides primarily positive feedback for eating while that from the stomach and small intestine provides primarily negative feedback. Initially, the brain is informed about the amount of food ingested and its nutrient content via afferent input. The gastrointestinal tract is equipped with specialised chemoand mechanoreceptors that monitor physiological activity and pass information to the brain, mainly via the vagus nerve. This afferent information constitutes one class of satiety signals and forms part of the post-ingestive control of appetite. A post-absorptive phase is also usually present in response to digested nutrients crossing the intestinal wall to enter the circulation. These products, which accurately reflect the food consumed, may be metabolised in the peripheral tissues or organs or may enter the brain directly via the circulation. In either case, these products constitute a further class of metabolic satiety signals. It has been argued that the degree of oxidative metabolism of glucose and free fatty acids in the liver constitutes a significant source of information for the control of appetite. Additionally, products of digestion and agents responsible for their metabolism may reach the brain and bind to specific chemoreceptors that influence that influence neurotransmitter synthesis or alter some aspect of neuronal metabolism. In each case the brain is informed about some aspects of metabolic state resulting from food consumption.

\section{Macronutrients and satiating power}

A vulnerable point within the psychobiological system is the interaction between the nature of the diet and the body's biological responses to food. The concept of the satiety cascade implies that foods of varying nutritional consumption will engage differently with the mediating processes and will, therefore, exert differing effects on satiation and satiety. Dietary variables could overcome appetite control by a strong attractiveness mediated by sensory mechanisms, by nutrient composition or by an interaction between sensory and nutritional components. Considering protein consumption, current surveys suggest that most populations consume between 13 and $15 \%$ daily energy as protein and dietary recommendations suggest the intake of $0.8-1.0 \mathrm{~g}$ of protein for every $\mathrm{kg}$ of body weight. However, analysis of anthropological evidence suggests the possibility that our hunter-gatherer ancestors may have consumed diets containing 19-35\% protein (Cordain et al. 2000). However, this view is not universally accepted (Milton, 2000).

Do the macronutrients protein, carbohydrate and fat contribute equally to satiating power? The answer is not 
obvious. One reason is that these macronutrients are not of equal caloric density, and therefore comparisons among them should be made on the basis of their individual caloric contributions rather than upon weight. Investigations of the action of macronutrients can be made by presenting preloads in which one macronutrient is held constant and the other two are varied systematically. For example, when fat is held constant and protein and carbohydrate adjusted, it is generally found that protein provides greater satiating power than carbohydrate. Therefore, high-protein meals would be expected to give rise to intense and prolonged satiety.

\section{Protein and satiety}

Evidence for a specific effect of protein on satiety goes back to the 'aminostatic' concept of appetite control (Mellinkoff et al. 1956). Early studies examined the effects of breakfast nutritional composition and found that highprotein breakfasts were followed by a consistent and prolonged 'sense of well-being', and that daily energy intake computed from diaries was inversely related to the protein content of breakfast. Unfortunately though, the outcomes of both studies were compromised by methodological shortfalls, such as not controlling for the energy content or bulk of the breakfast meals. Similar tantalising but problematic findings were reported for the effect of protein on subjective hunger. Fryer et al. (1955) noted that a highprotein weight-loss diet was associated with the least reports of hunger, and Mellinkoff et al. (1956) found an inverse correlational relationship between hunger and serum amino acid levels.

Later studies enabled firmer conclusions to be drawn regarding the satiating power of protein. Booth et al. (1970) evaluated the effects of equicaloric high- and lowprotein composite meals on the intake of a nutritionally intermediate cornflower pudding three hours later. Although the palatability of the food offered must be questioned, the authors nevertheless described a $26 \%$ reduction in voluntary intake after the high-protein meal. Using a completely different methodology, Butler et al. (1981) administered a small preload of an $8 \mathrm{~g}$ mixture of four amino acids or placebo $(134 \mathrm{~kJ})$ half an hour before offering a cooked midday meal. The amino acid preload led to a $10 \%$ reduction in energy intake from this meal compared with placebo.

Other studies have described the effects of high protein loads or meals on carefully measured scales of subjective motivation to eat. Spring et al. (1983) found that subjects reported feeling significantly more full after eating $227 \mathrm{~g}$ of turkey breast (high in protein) than after an equicaloric amount of high-carbohydrate sherbet. Likewise, Hill \& Blundell (1986) found that eating a high-protein lunchtime meal led subjects to rate themselves as having less desire to eat and as feeling more full than after an equicaloric and equivolume high-carbohydrate meal. A similar action of protein was also seen in obese subjects (Hill \& Blundell, 1986). Consequently, there is a good deal of evidence that high-protein foods can exert a potent modulation of human appetite. However, comparisons between different types of protein, such as egg albumin, casein, gelatin, soya protein, pea protein and wheat gluten, have failed to display differences arising from a manipulated meal (Lang et al. 1998).

\section{Proteins and satiety signalling}

Considering the operations of the satiety cascade, proteins in food could exert an action on satiety via the pre-absorptive or post-absorptive mechanism. In fact there is evidence for an action via both routes.

In general, proteins could intervene in the satiety cascade by triggering, or maintaining, the release of the satiety hormone cholecystokinin. There is good evidence in man that cholecystokinin intensifies normal satiety (Greenough et al. 1998) and in animals the satiety effect of protein has been shown to be mediated via cholecystokinin-A type receptors (Trigazis et al. 1997).

It is clear that intact protein can have a potent satietytriggering effect, but in addition specific amino acids or peptides could also exert a noticeable action. Individual amino acids such as phenylanine or tryptophan (Hill \& Blundell, 1988) have been shown to increase satiety and also adjust food preferences and selection. More recently, the dipeptide phenylalanine-aspartic acid, when delivered in capsule form before a meal, significantly reduced food consumption (Rogers \& Blundell, 1989). Interestingly, this effect was most prominent when the dipeptide was administered an hour before the meal (Rogers et al. 1995).

There seems to be a clear potential for other functional peptides such as caseinomacropeptide to exert a satietyenhancing effect. There is some evidence that caseinomacropeptide can release cholecystokinin and may modulate the release of other gastrointestinal hormones such as glucagon-like peptide-1, which is known to be involved in satiety (Blundell \& Naslund, 1999).

Proteins and peptides may also exert effects via a postabsorptive route. Important here is the concept of a hierarchy of satiety power among the macronutrients (Stubbs, 1996). This satiating concept depends upon the limited store of protein in the body (lean body mass) and the tight coupling between protein intake and oxidation. According to this formulation the hierarchy of satiating power is protein $>$ carbohydrate $>$ fats.

In addition, there is evidence for a strong effect of protein on diet-induced thermogenesis. A comparison between two diets demonstrated that the diet containing $29 \%$ protein produced a greater effect on $24 \mathrm{~h}$ diet-induced thermogenesis than a $9 \%$ protein diet (Westerterp-Plantenga et al. 1999).

Another post-absorptive mechanism depends upon the role of amino acids as precursors of brain neurotransmitters - for example, tryptophan for serotonin and phenylalanine and tyrosine for dopamine and noradrenalin. The capacity of these neurotransmitters to modulate the expression of appetite through brain systems can be influenced by the ratio of amino acids (e.g. tryptophan to large neutral amino acids) in the plasma.

These mechanisms indicate how protein exerts effects on satiety either as an entire food, a food component or as an isolated entity. Potent effects have been demonstrated for intact protein (Blundell \& Hill, 1986; Hill \& Blundell, 1990), dipeptides (Rogers et al. 1990, 1991) and single 
amino acids (Hill \& Blundell, 1988). This evidence indicates the potential for proteins to influence the intensity of satiety and to exert control over the pattern of food consumption.

\section{Carbohydrates and satiety}

There are strong logical reasons why glucose should be one of the most important nutrients to be monitored. As Carlson (1991) has pointed out: 'because the brain controls eating, it seems reasonable that hunger might be triggered by a decrease in the brain's primary fuel'. The idea that the metabolism of glucose in the body is related to the existence of hunger and eating is represented in the glucostatic hypothesis formulated by Mayer $(1953,1955)$. It was postulated that the short-term articulation of energy intake with energy needs is under glucostatic control (Van Itallie, 1990). In turn, this implies that dietary carbohydrates are clearly involved in the short-term control of energy intake. Similar views are embodied in the energostatic hypothesis (Booth, 1972), metabolic control of food intake (Friedman, 1991), the glycogenostatic hypothesis (Astrup \& Flatt, 1996) and the energetic concept of appetite (Blundell \& Rogers, 1991a). Although the most obvious mechanism is that hunger is related directly to fluctuations in the concentration of blood glucose, the relationship between energy intake and glucose could be mediated via arteriovenous glucose differences, the rate of glucose utilisation in the liver, the activation of glucoreceptive neurons in the periphery or the brain, or change in the glycogen stores. Evidence for the role of glucose in the initiation of eating comes from the detection of transient declines in blood glucose being related to meal initiation (Campfield \& Smith, 1986) and the observation that increases in energy intake follow injections of 2-deoxy-D-glucose (Thompson \& Campbell, 1977). Conversely, glucose infusions (particularly into the hepatic portal system) produce an inhibition of the tendency to eat (Novin et al. 1973). After the consumption of a carbohydrate food, the glucose produced could be monitored early by glucose-detecting interoreceptors in the upper gastrointestinal tract linked to visceral afferent fibres in the vagus nerve (Mei, 1985). In addition, Oomura (1988) has described glucose-sensitive neurons (which decrease their activity in response to applied glucose) and glucoreceptor neurons (which are activated) in different parts of the brain, which presumably provide an interface between the presence of available glucose and activity in aminergic or peptidergic neural pathways (Blundell, 1991). Apart from these direct links between the detection of glucose and neural transmission, an indirect mechanism has been postulated through which carbohydrate in the diet could be related to neurochemical activity. This mechanism relates the proportion of carbohydrate to protein in the diet to the ratio of tryptophan to other large neutral amino acids in plasma, which determines the uptake of tryptophan into the brain (Wurtman, 1982). In turn, it is postulated that this leads to an activation of serotoninergic neurons, which are functionally coupled to eating behaviour and food selection. The evidence for all stages in this biobehavioural loop is equivocal (Blundell \& Hill,
1987), but the ingestion of pure carbohydrate certainly alters the ratios of plasma amino acids (Teff et al. 1989). The mediator of this alteration is the glucose-induced release of insulin.

It follows that many mechanisms exist to monitor the activity of glucose released by ingested carbohydrates. Therefore, it should be possible to demonstrate a relationship between consumed carbohydrates and a modulation of the expression of appetite. Although sweet carbohydrates induce some positive feedback for eating through the induction of oral afferent stimulation by sweet receptors, this should be countered by the potent inhibitory action via post-ingestive and post-absorptive mechanisms (see below for effects of carbohydrates on cognitive performance and mood).

\section{Carbohydrates and appetite: experimental evidence}

On the basis of studies on rats, it was argued some years ago that: "if the cumulative inhibitory effects of carbohydrate on feeding are indeed energostatic ... then any substance that can readily be used by the animal to provide energy should produce an appropriate food intake compensation over a period of several hours after loading' (Booth, 1972). Studies have shown that this is also the case for man. A variety of carbohydrates, including glucose, fructose, sucrose, maltodextrin and polysaccharides, exert measurable effects when given in a preload or an experimental meal. That is, they suppress later intake by an amount roughly equivalent to their energy value, although the time course of the suppressive action may vary according to the rate at which the carbohydrates are metabolised.

The preload paradigm is a sensitive procedure for disclosing the effects of glucose and maltodextrin (glucose polymer) on appetite when these carbohydrates are delivered in a natural food product. For example, in a study using the uncoupling design (Blundell et al. 1988), the actions of sweetness and energy content of a yoghurt preload were separated experimentally by using judicious combinations of glucose, maltodextrins, high-intensity sweeteners and the yoghurt base (Rogers \& Blundell, 1989). After consumption, feelings of hunger were suppressed significantly by the high-energy preloads (glucose and maltodextrins) to a greater extent than after the lower-energy loads. Reduction of energy intake in the test meal was proportional to the energy difference $(678 \mathrm{~kJ})$ between the preloads. The accuracy of this adjustment confirms the frequent, though not universal, finding that human subjects adjust their voluntary intake in response to covert manipulations of the carbohydrate content of a food. In a more recent study, a comparison was made between preloads containing maltodextrin or sucrose compared with lower-energy loads with similar taste characteristics. At one hour after consumption, both high-energy preloads had suppressed intake compared with their lowenergy counterparts.

Taken together, these and other studies demonstrate that the preload design is a sensitive procedure for assessing the satiating power of carbohydrates. It appears that accurate adjustment of subsequent energy intake (often called energy compensation) is evident for glucose and 
maltodextrin. Measurement at one hour seems to be just about perfect for detecting the effects of these carbohydrates on satiety. However, this interval may not be appropriate for other carbohydrates (or for other macronutrients).

\section{Carbohydrate and the satiety index}

Over twenty years ago it was suggested that: it could be of great value to have tables showing the energy-satiety ratio of all the common foods to indicate their potential for causing over nutrition' (Heaton, 1981). Subsequently, the term 'satiating efficacy' was proposed 'as an index to compare the satiating potency of different foods' (Kissileff, 1984).

A further measure explored by Holt et al. $(1995,1999)$ relates the satiety response following a food to the satiety response following a reference food (white bread). Isoenergetic preloads $(1000 \mathrm{~kJ})$ of thirty-eight foods were consumed, following which subjective ratings of motivation to eat were completed over two hours. Significant differences in the satiating effects of the foods were seen, indicating that different foods differ in their satiating capacities. This novel approach quantifies the effects of a food on satiety and was based on the idea of developing a satiety index analogous to the glycaemic index. These studies showed that high-carbohydrate foods had a high satiety index measured by the satiety area under curve (AUC). The satiety index was positively correlated with the carbohydrate content of the foods tested.

A further measure has been termed the 'satiety quotient', which permits a measure of the effect of a food on satiation (within an eating episode) and satiety (the effect following eating). This allows determination of the degree of suppression of hunger that can be brought about per unit of food energy consumed (Green et al. 1997) and permits the tracking of changes over time. Using data from a variety of foods freely consumed, it was demonstrated that hunger was reduced more per $\mathrm{kJ}$ of carbohydrate food consumed than of high-fat food - but the strength of this varied with time. This finding confirms the proposal that, 'joule for joule', carbohydrate is more satiating than fat (Rolls et al. 1994).

\section{Evidence from nutritional interventions}

The results from short-term studies show clearly that carbohydrates exert a marked influence over the expression of appetite. Real-life intervention studies have demonstrated that this degree of appetite control has practical consequences. In one study, people identified as snackers were encouraged to eat $25 \%$ of their daily energy intake from high-carbohydrate or high-fat snacks during separate three-week periods. The subjects incorporated the snack foods into their normal eating repertoires and maintained a normal life-style. The study was monitored very carefully to ensure compliance to the experimental requirements and to assess food intake from the snack foods and from the rest of the eating pattern. Measures of total energy intake indicated that food consumption was physiologically valid and quite in keeping with body size and the level of physical activity. First, generous consumption of these palatable high-carbohydrate foods did not generate abnor- mally high energy intakes; indeed daily energy intake was an average of $364 \mathrm{~kJ}$ less than with the high-fat snacks - a value that could lead to a weight loss of approximately $3.5 \mathrm{~kg}$ over the course of a year. Second, the high-carbohydrate foods significantly lowered the total daily fat intake down to a level recommended in the National Dietary Guidelines (Lawton et al. 1998). Consequently this high-carbohydrate intervention, which was easily achieved, exerted a notable control over appetite and the pattern of nutrient intake.

In a series of studies carried out in Scotland, subjects were required to increase their consumption of highcarbohydrate breakfast cereals by $60 \mathrm{~g} / \mathrm{d}$ for twelve weeks (Kirk et al. 1997). This intervention resulted in a $5.4 \%$ reduction in energy from fat and a $5.1 \%$ increase in energy from starch. A second study with overweight men (body mass index $29.4 \mathrm{~kg} / \mathrm{m}^{2}$ ), who were required to increase their intake of high-carbohydrate breakfast cereal by $90 \mathrm{~g} / \mathrm{d}$ (approximately three bowls), led to an increase in carbohydrate consumption from 40 to $47 \%$ of total energy (Crombie \& Kirk, 1999). The positive changes in carbohydrate intake were accompanied by small weight losses.

Taken together, these studies show that a high intake of carbohydrate foods can lower fat intake and does not compromise energy balance.

\section{Fat and appetite control}

The effect of dietary fat on appetite and energy balance has been extensively researched and reviewed in the last ten years (Blundell et al. 1996). Owing to the high palatability and energy density of fatty foods, much of the evidence indicates the potential of high-fat products to cause overconsumption (Blundell \& Macdiarmid, 1997). However, there exists the 'fat paradox' which arises from the conflict between the capacity of fat to generate potent fat-induced satiety signals and the presence of high-fat hyperphagia (Blundell et al. 1995).

Because of the potency of fatty foods to stimulate a positive energy balance (partly through the process of passive consumption), it is important to develop procedures to mitigate this action. Three possibilities will be discussed here: (1) fat substitutes or fat mimetics, (2) specific types of fatty acids or triacylglycerols, and (3) modification of fats through processes such as fractionation.

Fat substitutes: evidence from Olestra. Olestra is the name of one of a class of compounds called sucrose polyesters. Olestra has the organoleptic properties of natural fat but it is not hydrolysed by lipases. Therefore, following consumption, it cannot produce metabolisable energy and can be regarded as possessing no calories. However, Olestra can be used in cooking and baking in similar ways to natural fat and it can therefore be incorporated into a wide range of foods. As a substitute for fat it therefore effectively reduces the fat content of foods and the fat energy absorbed by the body. Undigested Olestra passes straight through the gastrointestinal tract. The key issue is whether or not the consumption of Olestra-containing foods - with their reduced fat and energy contents - 
will lead to subsequent compensation, i.e. a later increase in the intake of fat and/or energy.

In short-term studies, one initial experiment in healthy, lean, young adult males found that the substitution of 20 or $36 \mathrm{~g}$ of fat by Olestra at a breakfast meal (Blundell et al. 1991; Rolls et al. 1994) led to full compensation during the course of the rest of the day. However, this study is atypical (probably because of the highly selected, well regulating subjects), and most studies have shown that the replacement of dietary fat with Olestra during one day does not cause full compensation during the next twentyfour hours. The replacement of $55 \mathrm{~g}$ of fat by Olestra at either lunch or dinner (Cotton et al. 1996) did not alter hunger or food intake during the test day or the following day. In a similar study, in which $55 \mathrm{~g}$ of Olestra was substituted in either three meals or five snacks across the course of one day, no effect was detected on hunger or food consumption. Therefore these studies indicate that Olestra can lead to a short-term reduction in the consumption of fat and energy.

Similar results have been obtained in longer-term studies. For example, when lean and obese subjects substituted an average of $26 \mathrm{~g}$ of fat per day for two weeks (Hill et al. 1998), total energy intake was reduced by $8 \%$ and fat intake by $11 \%$. This meant that subjects compensated for only $20 \%$ of the substituted energy.

However, the degree of compensation does appear to vary with the absolute level to which fat is reduced. When $55 \mathrm{~g}$ of Olestra reduced the percentage energy from fat in the diet from 32 to $20 \%$, a compensation of $67 \%$ was observed (Cotton et al. 1996). However, only $21 \%$ compensation was seen with a reduction of fat energy from 43 to $32 \%$. Taken together, several studies suggest that a reduction of fat energy down to generally recommended values (30-32\% of food energy per day) will not generate a strong hunger drive or tendency towards compensation. Interestingly, it does not seem to matter whether or not subjects have knowledge about the presence of a fat substitute in the foods being consumed (De Graaf et al. 1996; Miller et al. 1998). Importantly, in one longterm trial lasting for nine months, an Olestra-containing diet (reducing fat from 32 to $25 \%$ of energy) led to a reduction of $6.3 \mathrm{~kg}$ in body weight. These outcomes suggest that this strategy of fat substitution could be a useful approach to functional foods for appetite control.

Enhancing satiety: fatty acids. It has been noted earlier that foods containing a high percentage of fat have the capacity to promote over-consumption in obese (Lawton et al. 1993; Green et al. 1994a) subjects. This effect, which occurs during the process of 'satiation', is almost certainly due to the high energy density of high-fat foods, but the somewhat weaker effect of fat on 'satiety' is probably due to the physiological action of fat in generating post-ingestive inhibitory signals. Therefore the demonstration of varying effects of fats on satiety signalling could be useful in the development of fat-containing foods that modulate satiety. The induction of physiological satiety signals may well depend, at least in part, on the composition of fatty acids in the particular fats used. Two prominent structural features of fatty acids are their chain length and degree of saturation. In principle it is possible to manipulate both of these aspects. At the present time only a few studies have investigated these effects.

In two studies in which chain length was manipulated, medium-chain triacylglycerols have been shown to have greater satiating power than long-chain triacylglycerols (Rolls et al. 1988; Stubbs \& Harbron, 1995). A further study kept chain length constant and varied the degree of saturation (Lawton et al. 2000). This short-term study indicated that a meal containing largely monounsaturated fat induced a weaker satiety than polyunsaturated fat or a blend of saturated fat and monounsaturated fat. A second study produced a similar but less decisive outcome. Taken together, these and other studies suggest that monounsaturated fatty acids may exert a relatively weak effect on satiety. On the other hand, polyunsaturated fatty acids such as linoleic acid are worthy of further investigation for their relatively strong effect.

Enhancing satiety: novel treatments. It is known that fat, introduced directly into the gastrointestinal tract, can lead to an inhibition of eating that is mediated, at least in part, by the slowing of gastric emptying (Welch et al. 1985). The importance of these gastrointestinal responses means that if ingested fat (or fat-containing products) can resist digestion and reach the intestine, they may be able to induce a stimulation of satiety. One possible mechanism involved here is the so-called 'ileal brake' phenomenon. This concept has been invoked to explain the action of a specific treatment of fatty acids incorporated into yoghurt as an emulsion.

This emulsion, known, as Olibra, is a food ingredient containing fractionated palm oil and fractionated oat oil in the proportion 95:5. This emulsion contains more palmitic and linoleic acids, and less oleic acid, than milk fat. A yoghurt containing $5 \mathrm{~g}$ of the Olibra fat was given to subjects as a breakfast. In separate studies in lean (Burns et al. 2000) and obese (Burns et al. 2001) subjects, this single administration significantly reduced food intake throughout the whole day. This effect, which was accompanied by an increased sense of fullness and decreased hunger, was therefore maintained for up to eight hours. This is an extremely powerful effect. If an action of this intensity can be maintained with repeated administration, then the product could well become a functional food for appetite control. However, long-term weight-loss trials are required before any specific obesity-controlling effect can be claimed. Still, this novel manipulation suggests a potential route for developing fats with an enhanced action upon satiety.

\section{Interim summary for satiety}

Analysis of experimental studies indicates that all foods share certain common features (weight, volume, texture) which contribute to their effects on satiation and satiety. However, the nutritional composition also plays a key role and markedly modulates the intensity and duration of satiety and the strength of satiation. This means that the macronutrient composition of foods can favour consumption (and over-consumption) and also limit the amount of food willingly consumed and the motivational feelings associated with eating. The macronutrients 
protein, carbohydrate and fats differ in their mechanisms of inducing satiety and also vary in their impact on the size and frequency of eating episodes. Therefore many opportunities exist for targeted manipulations of proteins, fats and carbohydrates in the development of functional foods for appetite control.

\section{Biomarkers for appetite}

A biomarker can be defined as a surrogate endpoint that can be used instead of some clinical endpoint. How can this be applied to a behavioural or psychological function such as appetite control? If the ultimate objective of a functional food for appetite control is the reduction or maintenance of food intake, then a surrogate or 'proxy' for this could be the profile of subjective hunger that oscillates with the pattern of food intake and is usually well correlated with the amount of food consumed (when hunger fails to correlate with food eaten there are usually good reasons). Consequently, it can be proposed that subjectively perceived hunger - translated into an objective end- point by means of the visual analogue rating scale - can be regarded as an objective biomarker for appetite control.

\section{Functional foods for cognitive performance}

\section{Measurement of cognitive processes}

In principle, a large number of mental or cognitive tasks have the potential to disclose the effects of foods. However, in practice, a limited number of tests have been used. Performance tasks reflect a number of cognitive functions; for example, perception, memory, attention and arousal, information processing, accuracy and speed of movement (Bellisle et al. 1998). These tasks represent single components of performance, which form part of more complex skills and abilities (see Table 1); for example, car-driving ability or operating machinery. Cognitive performance encompasses not only measures of speed (reaction time) but also of processing accuracy (measures of accurate and inaccurate detection). Interventions may elicit

Table 1. Functions assessed by cognitive tests

\begin{tabular}{|c|c|c|}
\hline Function & Example of tests & Common components of task \\
\hline $\begin{array}{l}\text { Reaction time (decision time and } \\
\text { movement time) }\end{array}$ & Simple (SRT) or choice (CRT) & $\begin{array}{l}\text { Stimulus appears (visual or auditory) } \\
\text { and S must make a single response, } \\
\text { usually by depressing a key. In CRT } \\
\text { one of a number of stimuli may } \\
\text { appear and S must make one of } \\
\text { two responses (e.g. left hand, right hand) } \\
\text { according to the type of stimulus }\end{array}$ \\
\hline \multirow[t]{3}{*}{$\begin{array}{l}\text { Vigilance (also known as attention), } \\
\text { rapid information processing or } \\
\text { continuous performance }\end{array}$} & $\begin{array}{l}\text { Search tests, e.g. } \\
\text { - categoric search }\end{array}$ & $\begin{array}{l}\text { Detection of stimulus items from particular } \\
\text { categories }\end{array}$ \\
\hline & $\begin{array}{l}\text { - Digit symbol substitution } \\
\text { - Stroop }\end{array}$ & $\begin{array}{l}\text { S must replace digits with symbols } \\
\mathrm{S} \text { must attend to certain features of stimuli } \\
\text { and ignore others }\end{array}$ \\
\hline & - Bakan & $\begin{array}{l}\text { A series of numbers are presented visually } \\
\text { in rapid succession on a VDU screen. } \\
\mathrm{S} \text { has to respond by depressing a key } \\
\text { when a sequence of three odd or three } \\
\text { even digits is detected }\end{array}$ \\
\hline \multirow{8}{*}{$\begin{array}{l}\text { Visual information processing } \\
\text { Frontal executive } \\
\text { Working memory } \\
\quad \text { (short-term memory) }\end{array}$} & Critical flicker fusion threshold & S must detect flicker and fusion of light \\
\hline & Immediate recall & $\mathrm{S}$ shown a list of stimuli at a given rate \\
\hline & & $\begin{array}{l}\text { (e.g. one per second). At end of } \\
\text { presentation } S \text { recalls the stimuli }\end{array}$ \\
\hline & Verbal memory & S must recognise rather than recall \\
\hline & Spatial memory & S must discriminate or recognise patterns \\
\hline & Associative memory & \\
\hline & Word recognition & \\
\hline & Pattern comparison & \\
\hline Immediate memory & Digit span & $\begin{array}{l}\text { S must remember (recall) series of items } \\
\text { in forward or reverse order }\end{array}$ \\
\hline Reasoning & $\begin{array}{l}\text { Arithmetic, logical, grammatical or } \\
\text { semantic }\end{array}$ & $\begin{array}{l}\text { S must process and indicate if stimulus } \\
\text { (phrase, equation or expression) is true } \\
\text { or false }\end{array}$ \\
\hline \multirow[t]{3}{*}{$\begin{array}{l}\text { Psychomotor performance } \\
\text { (tracking ability) }\end{array}$} & Driving simulation & $\begin{array}{l}\text { Tracking and deviation on a course are } \\
\text { monitored continuously }\end{array}$ \\
\hline & Visuo-spatial motor task & Simulator/driving task \\
\hline & Tapping task & S must tap in rapid succession to a key \\
\hline
\end{tabular}


changes in function in some or all of these performance components.

In choosing a task much depends on whether an immediate (short-term) effect of food is expected or whether a chronic long-term adaptation to a diet is being examined. The former and arguably more simple approach is the focus of most current research. Measures that are frequently utilised in assessing the effects of nutrients include reaction time, attention and memory. Other tests have also been used but selection is frequently based on accessibility rather than likely effect of a nutrient on a particular cognitive process. The proposed mechanism of action of a nutrient in terms of its effects on blood glucose or other neurotransmitter systems and the likely effects of changes in these neurobiological parameters on cognitive processes have not been considered. Thus a failure to detect an effect of a particular macronutrient on a particular aspect of cognitive function may be due to a true lack of effect, because the neuropsychological processes needed to perform the task are unaffected by the nutrient ingested. The effect of compensatory effort in experimental situations — 'the Hawthorne effect' (Roethlisberger, 1997) - is well known and can account for null results. Alternatively, the intervention may affect only a small component of the task (e.g. reaction time or decision time) such that an effect on overall performance is not detected. Recent advances in computer technology have meant that these tasks can be administered in a structured, carefully controlled fashion, with extremely accurate measurement of processing and reaction time, correct responses and error rates. Examination of the pattern of effects on sub-processes within a task or on simple unitary measures of cognition may be helpful in determining the mechanism of action or neurotransmitter systems involved or affected by the nutrient ingested.

\section{Effects of foods on cognitive performance}

Various studies have examined the effects of nutritional interventions across a range of cognitive domains. The effects of these manipulations on each of the major areas of cognitive performance are summarised below.

Reaction time. Reaction time may be measured as a response to a variety of stimuli. Visual or auditory stimuli are presented and response time is measured. Simple or choice reaction time can be employed, requiring the participant to respond selectively to stimuli which have particular features, e.g. frequency, colour, spatial position, tone, etc. Thus the reaction time task can comprise more than one cognitive process. In addition, the reaction time recorded can be broken down into movement and detection components.

Studies that examine the effects of macronutrients on reaction time are described in Table 2. The main conclusions of this body of research can be summarised as follows.

1. Effects are more clearly demonstrable in the morning (particularly breakfast studies).

2. Nutritional interventions, which facilitate a rise in blood glucose, enhance performance of reaction time tasks.

3. The findings of studies of macronutrients given in combination suggest that fat may slow reaction time; carbohydrate can impair peripheral processing and reaction time, depending on the time of day and type of carbohydrate ingested as well as ratio of carbohydrate to protein.

4. Foods that facilitate speed of reaction should enhance glucose availability, e.g. high glycaemic index. There have been no studies that specifically compare the effects of foods with different glycaemic indices. One study (Kaplan et al. 2001) found similar improvements in memory after high- and low-glycaemic-index carbohydrates in the elderly.

Attention and vigilance. Vigilance or attention tasks have been included in a large number of studies that aim to assess the effects of nutrients on performance. The nature of the task employed often differs and it is sometimes difficult to determine whether the cognitive processes that may be involved in each task are similar or comparable. Digit symbol substitution and the Bakan test have frequently been employed (see Table 3). However, some studies do not adequately describe the specific test used.

The effects of nutrients on attention and vigilance, as described in Table 3, can be summarised as follows.

1. Attention can be difficult to disrupt in the first half of the day but seems susceptible to fat ingestion at lunch and later. It can be disrupted by high carbohydrate and effects of this are most clear in terms of response time measures.

2. Effects could be due to an impairment of either detection or movement, but work on reaction time measures would suggest that movement is the most vulnerable cognitive process.

3. Although participants appear to be slower, there is some suggestion that they are also more accurate, which could imply criterion shifts.

4. Protein appears to influence susceptibility to distraction.

5. The suggestion that attention can be enhanced by energy requires verification.

Memory. Examination of functional food effects on measures of memory has focused on short-term or working memory (see Table 4). Tests employed usually require immediate recall of a word list or similar stimuli presented at a fixed rate, after which the subject is required to repeat or write down as many of the stimuli as possible in a fixed period of time. The number of items in the word list is usually twenty to thirty in normal volunteer samples and seven plus or minus two words should be the average number recalled. Some samples, notably students, recall almost double this rate, partly due to the effects of training and intelligence. Two effects are common in memory tasks. Primacy and recency effects relate to the increased likelihood of recalling the earliest and latest stimuli from a list, although few studies examine the order of words recalled or request that the subject recalls the stimuli in the order presented. The nature of the stimulus words are 
also important since efficiency of recall can be affected by differences in the frequency, concreteness and imagery of the words used as stimuli. It is therefore important that memory tasks select and match stimuli on these features. Other types of memory tasks sometimes employed include delayed recall, where the subject is required to recall a list presented some time earlier (usually ten to twenty minutes) and has had to perform other tasks in the interim period. Recognition recall requires the subject to identify stimuli that were presented earlier from a list that includes unseen, distractor stimuli. Recognition recall is generally easier than free recall. Pattern comparison is another form of memory task that examines spatial memory performance. Paired associate learning involves remembering two paired but semantically unrelated stimuli and recalling one of the pair when the other is presented. Although there are many variants of memory tasks, those used in the assessment of nutrients have been limited.

A summary of the effects of nutrients on memory, outlined in Table 4, is given in the following.

1. Glucose appears reliably to improve memory, particularly in vulnerable subjects such as the young and elderly.

2. Pure carbohydrate in other forms improves memory but can impair peripheral processing, attention and reaction time, depending on the time of day, type of carbohydrate ingested and ratio of carbohydrate to protein. It is also associated with feelings of fatigue.

3. The carbohydrate:protein of a meal can produce depletion or enhancement of tryptophan (Klassen et al. 1999). Where tryptophan availability is enhanced, faster memory scanning has been demonstrated in stress-prone subjects who may have receptor sensitisation of the serotoninergic system or 5hydroxytryptamine (5-HT) deficiency (Markus, 1999).

4. Tryptophan depletion selectively impairs memory consolidation in normal volunteers (Riedel et al. 1999).

5. Thus memory tasks appear to be important measures of cognitive function, which are susceptible to nutritional manipulations.

Other aspects of performance. A large number of cognitive tests can be used to examine the effects of nutrients on performance and which measure functions other than attention and memory.

Psychomotor performance involving hand-eye coordination can be used to reflect the kind of cognitive processes involved in operating machinery or driving. These tasks may feature reaction time measures but are generally more complex performance indicators than the tests reviewed in the section on reaction time above. The effect of macronutrients on these performance measures is shown in Table 5. The simplest form of psychomotor task, which has been used reasonably widely in this area, is the tapping task. Dieters performed better on a finger-tapping test in the morning (Deijen et al. 1989). Lloyd et al. (1994, 1996) also used a tapping task to assess breakfast and lunch manipulations.

More complex psychomotor tasks involve tracking and control. Driving can be considered to be an ecologically valid psychomotor task and real or simulated driving tasks are used to establish the effects of drugs or other interventions on actual driving and driver safety. There have been a small number of studies examining nutrient effects on performance, which have used tracking or driving simulator tasks. Performance of a tracking task was better in a group of cadets after repeated consumption of a tyrosine-rich drink than in the group supplied with a carbohydrate-rich drink (Deijen et al. 1999). Smith \& Rich (1998) examined the effect of no snack, a chocolate bar or an equicaloric portion of cheese and biscuits on simulated driving. Following consumption of the chocolate, subjects drove more carefully and hit the side of the track less often. It is difficult to determine from this manipulation whether any specific ingredient in the chocolate was predominantly affecting the performance although the caffeine content is not likely to be high enough to have an alerting effect. An alternative explanation is that mood may have been modified differentially across the three conditions (foods were not matched for taste, appearance and palatability) and this could have mediated the performance effects observed.

Other tests assess perceptual processes such as vision. Such tests have been used widely in assessing the importance of the essential fatty acid, docosahexaenoic acid, in neural maturation, visual acuity and brain function in ageing (Horrocks \& Yeo, 1999). The effect of docosahexaenoic acid supplementation on cognitive performance in healthy young adults has not been examined specifically. Another widely used test in psychopharmacology is Critical Flicker Fusion Threshold, which involves the discrimination of flicker from fusion and is an index of cortical arousal and visual information processing capacity. Visual information processing (measured by Critical Flicker Fusion Threshold) was increased significantly by a decaffeinated Coca-Cola drink with added tryptophan, compared with a decaffeinated Coca-Cola drink alone (Cunliffe et al. 1998). This effect of amino acid manipulation suggests impairment of performance follows protein consumption. Fat ingestion has also been shown to decrease flicker fusion frequency, indicating increased central fatigue or decreased visual information processing capacity (Cunliffe et al. 1997).

Other cognitive tasks such as reasoning tasks (involving logical, semantic and grammatical reasoning), problemsolving tasks and arithmetic tasks have also been employed in studies of nutrient effects. Addition and sentence verification tasks are not affected by missing breakfast (Dickie \& Bender, 1982; Smith \& Kendrick, 1992; Smith et al. 1994a). Smith et al. (1994b) showed that a high-fat lunch did not affect logical reasoning. In comparison with performance after a diet soft-drink (containing aspartame), subjects solved more arithmetic problems in a shorter time after consuming calorie-containing yoghurts (Kanarek \& Swinney, 1990).

Providing a supplementation of branched-chain amino acids has also been shown to prevent impairment of performance of shape rotation and identification tasks and to improve performance of the Stroop task after exercise 


\begin{tabular}{|c|c|c|c|c|c|}
\hline Reference & Sample & Study design & Cognitive testing & Effect on performance of task & Comments \\
\hline $\begin{array}{l}\text { Spring } \\
\quad \text { et al. } \\
\text { (1983) }\end{array}$ & $\begin{array}{l}184 \text { healthy } \\
\text { adults } \\
(129 \mathrm{M}, \\
\text { fifty-five F), } \\
18-65 \text { years }\end{array}$ & $\begin{array}{l}\text { Two meals for BK or lunch: } \\
\text { - HCHO (non-dairy sherbet) } \\
\text { - HP (turkey breast) }\end{array}$ & $\begin{array}{l}\text { Auditory RT } \\
\text { Assessment } 2 \mathrm{~h} \text { after } \\
\text { consuming the meal }\end{array}$ & No effect & $\begin{array}{l}\text { No pre-meal measure of } \\
\text { performance } \\
\text { Between-subjects design } \\
\text { Foods were not BK or lunch } \\
\text { standard items }\end{array}$ \\
\hline $\begin{array}{l}\text { Lieberman } \\
\text { et al. } \\
\text { (1983) }\end{array}$ & Young men & $\begin{array}{l}\text { Two lunches: } \\
\text { - HCHO (pita bread) } \\
\text { - HP (turkey breast) }\end{array}$ & $\begin{array}{l}\text { Auditory RT } \\
\text { Assessment after lunch }\end{array}$ & $\begin{array}{l}\text { Slower RT to an auditory } \\
\text { stimulus after the HCHO meal } \\
\text { than after the HP meal }\end{array}$ & $\begin{array}{l}\text { No baseline measures of } \\
\text { cognitive performance }\end{array}$ \\
\hline $\begin{array}{l}\text { Smith \& } \\
\quad \text { Miles } \\
\quad(1986 b, c)\end{array}$ & $\begin{array}{l}\text { Forty-eight } \\
\text { subjects }\end{array}$ & $\begin{array}{l}\text { Two conditions: } \\
\text { - lunch } \\
\text { - no lunch }\end{array}$ & $\begin{array}{l}\text { Serial self-paced CRT } \\
\text { (detection RT and } \\
\text { movement time) } \\
\text { Assessment before and after } \\
\text { lunch }\end{array}$ & $\begin{array}{l}\text { Lunch consumption impaired } \\
\text { detection time (RT) on CRT } \\
\text { Movement time slower in early } \\
\text { afternoon than in morning, } \\
\text { independent of meal } \\
\text { consumption }\end{array}$ & \\
\hline $\begin{array}{l}\text { Smith } \\
\text { et al. } \\
\text { (1988) }\end{array}$ & $\begin{array}{l}\text { Five } M \text { and } \\
\quad \text { six } F\end{array}$ & $\begin{array}{l}\text { Three iso-energetic lunches } \\
\text { (3.77 MJ in M, } 2.72 \mathrm{MJ} \text { in F): } \\
\text { - HCHO, high in starch } \\
\text { (40\% starch, } 15 \% \text { sugar, } \\
15 \% \text { protein, } 30 \% \text { fat) } \\
\text { - HCHO, high in sugar } \\
\text { (15\% starch, } 40 \% \text { sugar, } \\
15 \% \text { protein, } 30 \% \text { fat) } \\
\text { - HP (14\% starch, } 1 \% \text { sugar, } \\
55 \% \text { protein, } 30 \% \text { fat) }\end{array}$ & $\begin{array}{l}\text { RT-focused attention test } \\
\text { Assessment before and } \\
75 \text { min following lunch }\end{array}$ & $\begin{array}{l}\text { Slower RT to peripheral targets } \\
\text { after the } \mathrm{HCHO} \text { meals than } \\
\text { after the HP meal }\end{array}$ & \\
\hline $\begin{array}{l}\text { Lloyd et al. } \\
\quad(1994)\end{array}$ & $\begin{array}{l}\text { Eighteen subjects } \\
\quad \text { (fifteen F, } \\
\text { three M), } \\
\text { mean age } \\
27 \text { years }\end{array}$ & $\begin{array}{l}\text { Three iso-caloric lunches } \\
\text { (about } 2 \cdot 92 \mathrm{MJ}): \\
\text { - LF/HCHO (2.90 MJ, 29/54\% en) } \\
\text { - MF/MCHO (2.95 MJ, } 45 / 42 \% \text { en) } \\
\text { - MHF/LCHO (3.01 MJ, } 62 / 24 \% \text { en) }\end{array}$ & $\begin{array}{l}\text { SRT } \\
\text { Assessment } 30 \mathrm{~min} \text { before } \\
\text { lunch, } 30 \mathrm{~min}, 90 \mathrm{~min} \text { and } \\
150 \mathrm{~min} \text { after finishing } \\
\text { lunch }\end{array}$ & $\begin{array}{l}\text { Longer RT after LF and HF } \\
\text { lunches, compared with the MF } \\
\text { lunch, at } 90 \text { min post ingestion }\end{array}$ & $\begin{array}{l}\text { The MF/CHO meal was most similar } \\
\text { in size and macronutrient content } \\
\text { to the subject's habitual lunch. } \\
\text { Results may reflect responses to } \\
\text { changes in normal intake rather } \\
\text { than to the specific macronutrient } \\
\text { composition of the meals }\end{array}$ \\
\hline $\begin{array}{l}\text { Smith } \\
\text { et al. } \\
\quad(1994 c)\end{array}$ & $\begin{array}{l}\text { Experiment 1: } \\
\text { forty-eight } \\
\text { university } \\
\text { students } \\
\text { (twenty-four } \\
\text { M, twenty- } \\
\text { four F) }\end{array}$ & $\begin{array}{l}\text { Six conditions: } \\
\text { - no BK + decaffeinated coffee } \\
\text { - cereal toast BK (equivalent to } \\
\text { LF) + decaffeinated coffee } \\
\text { - cooked BK (equivalent to } \\
\text { HF) + decaffeinated coffee } \\
\text { - no BK + caffeinated coffee } \\
\text { - cereal toast BK (equivalent to } \\
\text { LF) + caffeinated coffee } \\
\text { - cooked BK (equivalent to } \\
\text { HF) + caffeinated coffee }\end{array}$ & $\begin{array}{l}\text { SRT } \\
\text { Five-choice serial response } \\
\text { time (CRT) } \\
\text { Assessment } 30 \text { min before } \\
\text { BK, } 60 \text { and } 120 \text { min after } \\
\text { the start of BK }\end{array}$ & $\begin{array}{l}\text { No effect of BK on performance } \\
\text { on SRT or CRT }\end{array}$ & $\begin{array}{l}\text { Between-subject design } \\
\text { BK differs from lunch } \\
\text { Caffeine enhanced performance of } \\
\text { SRT but had no effect on CRT }\end{array}$ \\
\hline $\begin{array}{l}\text { Smith } \\
\text { et al. } \\
(1994 c)\end{array}$ & $\begin{array}{l}\text { Experiment 2: } \\
\text { forty-eight } \\
\text { university } \\
\text { students } \\
\text { (twenty-four M, } \\
\text { twenty-four F) }\end{array}$ & $\begin{array}{l}\text { Four conditions: } \\
\text { - three-course meal }(5.02- \\
6.28 \mathrm{MJ})+ \text { decaffeinated drink } \\
\text { - three-course meal }(5.02- \\
6.28 \mathrm{MJ})+ \text { caffeinated drink } \\
\text { - no meal + decaffeinated drink } \\
\text { - no meal + caffeinated drink }\end{array}$ & $\begin{array}{l}\text { SRT } \\
\text { Five-choice serial response } \\
\text { task (CRT) } \\
\text { Assessment before the meal } \\
\text { and } 90 \mathrm{~min} \text { and } 180 \mathrm{~min} \text { after } \\
\text { the start of the meal }\end{array}$ & No effects on tasks & $\begin{array}{l}\text { Effects are different from those } \\
\text { observed after lunch or BK }\end{array}$ \\
\hline
\end{tabular}


- HF/LCHO (3.18MJ, 55/40\% en)

- LF/HCHO (3.60 MJ, 88/7\% en)

Group A: ate meals at 10.30

$$
\text { (brunch) }
$$

Group B: BK (08.15) and test meal at 12.30 (lunch)

\begin{tabular}{|c|c|c|c|c|c|}
\hline $\begin{array}{l}\text { Cunliffe } \\
\text { et al. } \\
\text { (1997) }\end{array}$ & $\begin{array}{l}\text { Sixteen healthy } \\
\text { volunteers } \\
\text { (nine } \mathrm{M} \text {, } \\
\text { seven } \mathrm{F} \text { ), } \\
\text { aged } 20-47 \text { years } \\
\text { (mean, } 29.7 \text { years) }\end{array}$ & $\begin{array}{l}1672 \mathrm{~kJ} \text { at BK of approx. } 200 \mathrm{ml}: \\
\text { - pure } \mathrm{CHO} \text { (maltodextrin) } \\
\text { - pure fat (long-chain triacylglycerol } \\
\text { emulsion) } \\
\text { Control: mixed } \mathrm{CHO} \text {, fat and protein } \\
\text { ( } 55 \% \mathrm{CHO}, 15 \% \text { protein, } 30 \% \text { fat, } \\
\text { same sources of } \mathrm{CHO} \text { and fat) }\end{array}$ & $\begin{array}{l}\text { Simple visual reaction time } \\
\text { Hourly for } 4 \mathrm{~h} \text { post ingestion }\end{array}$ & $\begin{array}{l}\text { Slower after } \mathrm{CHO} \\
\text { No effect of fat on RT }\end{array}$ & \\
\hline $\begin{array}{l}\text { Lloyd et al. } \\
\quad(1996)\end{array}$ & $\begin{array}{l}\text { Sixteen healthy } \\
\text { habitual BK eaters } \\
\text { (fourteen F, two M), } \\
\text { age } 26 \text { years }\end{array}$ & $\begin{array}{l}\text { Four conditions: } \\
\text { - no BK } \\
\text { - three iso-caloric BK }(2.51 \mathrm{MJ}) \text { : } \\
\text { - LF/HCHO }(27 / 62 \% \text { en }) \\
\text { - MF/MCHO (44/47\% en) } \\
\text { - HF/LCHO (56/34\% en) }\end{array}$ & $\begin{array}{l}\text { SRT } \\
\text { Assessment beginning } \\
30 \mathrm{~min} \text { before, and } 30 \mathrm{~min} \text {, } \\
90 \mathrm{~min} \text { and } 150 \mathrm{~min} \text { after BK }\end{array}$ & $\begin{array}{l}\text { No clear difference in } \\
\text { performance between the } \\
\text { four conditions }\end{array}$ & $\begin{array}{l}\text { BK provided in the study was higher } \\
\text { in en than usual BK }\end{array}$ \\
\hline $\begin{array}{l}\text { Fischer } \\
\text { et al. } \\
\text { (2001) }\end{array}$ & Fifteen young males & $\begin{array}{l}1670 \mathrm{~kJ} \text { at breakfast, } \\
\text { spoonable creams of: } \\
\text { - pure fat } \\
\text { - pure } \mathrm{CHO} \\
\text { - pure protein }\end{array}$ & $\begin{array}{l}\text { Simple and choice RT } \\
\text { Hourly for } 3 \mathrm{~h} \text { post ingestion }\end{array}$ & $\begin{array}{l}\text { Fat improved RT performance } \\
\text { compared with baseline at } 1,2 \\
\text { and } 3 \mathrm{~h} \text {, and reduced error rate } \\
\text { No effect of } \mathrm{CHO} \text { on SRT } \\
\mathrm{CHO} \text { improved CRT at } 1 \mathrm{~h} \\
\text { CHO impaired CRT at } 2 \mathrm{~h} \\
\text { Protein improved CRT at } 2 \mathrm{~h}\end{array}$ & \\
\hline $\begin{array}{l}\text { Lluch et al. } \\
\qquad(2000)\end{array}$ & $\begin{array}{l}\text { Thirty-two } \\
\text { volunteers } \\
\text { (sixteen M and } \\
\text { sixteen F; } \\
\text { seventeen } \\
\text { LF and fifteen } \\
\text { HF consumers) }\end{array}$ & $\begin{array}{l}\text { Two iso-caloric BK (1.72 MJ) } \\
\text { and lunches (3.10 MJ for F, } \\
4.14 \mathrm{MJ} \text { for M) } \\
\text { - LF/HCHO (BK: } 22 / 67 \% \text { en, } \\
\text { lunch: } 20 / 61 \% \text { en) } \\
\text { - HF/LCHO (BK: } 48 / 42 \% \text { en, } \\
\text { lunch: } 54 / 32 \% \text { en) }\end{array}$ & $\begin{array}{l}\text { Simple and choice RT } \\
\text { Assessment just before and } \\
30 \text { min after finishing lunch }\end{array}$ & $\begin{array}{l}\text { Slower RT after HF lunch than } \\
\text { after LF lunch } \\
\text { No effect of habitual diet on } \\
\text { performance }\end{array}$ & \\
\hline
\end{tabular}

BK, breakfast; $\mathrm{CHO}$, carbohydrate; CRT, choice reaction time; en, energy; F, female; HCHO, high carbohydrate; HF, high fat; HP, high protein; LCHO, low carbohydrate; LF, low fat; M, male; MCHO, medium carbohydrate; MF, medium fat; RT, reaction time; SRT, simple reaction time.
Serial choice reaction

Overall little change in

performance

performancence in

$30 \mathrm{~min}$ before, and $30 \mathrm{~min}$

$90 \mathrm{~min}$ and $150 \mathrm{~min}$ after $\mathrm{BK}$

Simple and choice R

Hourly for $3 \mathrm{~h}$ post ingestion

after LF lunch

Ample and choice RT

30 min after finishing lunch
No effect on SRT 
Table 3. Effect of nutrients on attention tasks

\begin{tabular}{|c|c|c|c|c|c|}
\hline Reference & Sample & Study design & Cognitive testing & Results & Comments \\
\hline $\begin{array}{l}\text { Spring et al. } \\
\quad(1983)\end{array}$ & $\begin{array}{l}184 \text { healthy adults } \\
\text { (129 M, fifty-five } \\
\text { F), } 18-65 \text { years }\end{array}$ & $\begin{array}{l}\text { Two meals for BK or lunch: } \\
\text { - HCHO (non-dairy sherbet) } \\
\text { - HP (turkey breast) }\end{array}$ & $\begin{array}{l}\text { Dichotic shadowing (sustained } \\
\text { and selective aspects of } \\
\text { attention) } \\
\text { Assessment } 2 \mathrm{~h} \text { after } \\
\text { consuming the meal }\end{array}$ & $\begin{array}{l}\text { Impairment on the sustained } \\
\text { selective attention task after } \\
\mathrm{HCHO} \text { lunch compared with HP } \\
\text { in subjects over } 40 \text { years of age }\end{array}$ & $\begin{array}{l}\text { No pre-meal measure of } \\
\text { performance } \\
\text { Between-subjects design } \\
\text { Foods were not BK or } \\
\text { lunch standard items }\end{array}$ \\
\hline $\begin{array}{l}\text { Lieberman } \\
\text { et al. } \\
\text { (1983) }\end{array}$ & Young men & $\begin{array}{l}\text { Two lunches: } \\
\text { - HCHO (pita bread) } \\
\text { - HP (turkey breast) }\end{array}$ & $\begin{array}{l}\text { DSST } \\
\text { Assessment after lunch }\end{array}$ & $\begin{array}{l}\text { Poorer performance on a DSST } \\
\text { after the HCHO meal than after } \\
\text { the HP meal }\end{array}$ & $\begin{array}{l}\text { No baseline measures of } \\
\text { cognitive performance }\end{array}$ \\
\hline $\begin{array}{l}\text { Smith et al. } \\
\quad(1988)\end{array}$ & Five $M$ and six $F$ & $\begin{array}{l}\text { Three iso-energetic lunches } \\
\text { ( } 3.77 \mathrm{MJ} \text { in } \mathrm{M}, 2.72 \mathrm{MJ} \text { in } \mathrm{F}) \text { : } \\
\text { - HCHO, high in starch } \\
\text { (40\% starch, } 15 \% \text { sugar, } \\
15 \% \text { protein, } 30 \% \text { fat) } \\
\text { - HCHO, high in sugar } \\
\text { (15\% starch, } 40 \% \text { sugar, } \\
15 \% \text { protein, } 30 \% \text { fat) } \\
\text { - HP (14\% starch, } 1 \% \text { sugar, } \\
55 \% \text { protein, } 30 \% \text { fat) }\end{array}$ & $\begin{array}{l}\text { Assessment before and } 75 \mathrm{~min} \\
\text { following lunch }\end{array}$ & $\begin{array}{l}\text { Slower RT to peripheral targets } \\
\text { after the HCHO meals than after } \\
\text { the HP meal } \\
\text { Susceptibility to distracting stimuli } \\
\text { greater after the HP lunch than } \\
\text { after the HCHO meals }\end{array}$ & \\
\hline $\begin{array}{l}\text { Deijen et al. } \\
\quad(1989)\end{array}$ & $\begin{array}{l}\text { Two groups: } \\
\text { - control }(n=9) \\
\text { - diet }(n=10) \\
21-27 \text { years }\end{array}$ & $\begin{array}{l}\text { During three weeks, diet group } \\
\text { had a daily intake of } 110 \mathrm{~g} \\
\text { protein, } 320 \mathrm{~g} \mathrm{CHO} \text { and } 80 \mathrm{~g} \text { fat } \\
\text { - BK: } 70 \mathrm{~g} \text { protein }(63 \%), \\
\text { 25 g CHO (8\%) } \\
\text { - lunch: } 10 \mathrm{~g} \text { protein }(9 \%), \\
100 \mathrm{~g} \mathrm{CHO}(31 \%)\end{array}$ & $\begin{array}{l}\text { Sustained visual attention task } \\
\text { Pattern comparison } \\
\text { DSST } \\
\text { Assessment: baseline scores } \\
\text { (last day of } 3 \text { weeks, after BK } \\
\text { and dinner) and post-treatment } \\
\text { scores (2 months later) }\end{array}$ & No effect on attention type tasks & \\
\hline $\begin{array}{l}\text { Benton } \\
\text { et al. } \\
\text { (1994) }\end{array}$ & $\begin{array}{l}\text { Seventy young } \\
\text { female } \\
\text { students }\end{array}$ & $\begin{array}{l}\text { Glucose drink }(50 \mathrm{~g}) \text { after } \\
\text { baseline and } 25 \text { min later } \\
(25 \mathrm{~g}) \text { or CHO-free placebo } \\
\text { drinks (sweetened with } \\
\text { aspartame and acesulfame K) }\end{array}$ & Reaction to Bakan test & Improved decision time & $\begin{array}{l}\text { Between-subjects design, } \\
\text { no dietary restrictions } \\
\text { on test day }\end{array}$ \\
\hline \multirow[t]{2}{*}{$\begin{array}{l}\text { Kelly et al. } \\
\text { (1994) }\end{array}$} & \multirow[t]{2}{*}{$\begin{array}{l}\text { Experiment 1: } \\
\text { two groups } \\
\text { of six subjects }\end{array}$} & $\begin{array}{l}\text { Four lunches varying in energy and } \\
\text { fat and carbohydrate content } \\
\text { - LF/low en (1.80 MJ) }\end{array}$ & $\begin{array}{l}\text { Choice of tasks: } \\
\text { - DSST }\end{array}$ & $\begin{array}{l}\text { Performance on the task was } \\
\text { poorer after compared with before } \\
\text { the meal } \\
\text { No systematic variations in } \\
\text { performance as a consequence of } \\
\text { either the energy or macronutrient } \\
\text { content of the meals }\end{array}$ & $\begin{array}{l}\text { Limited number of } \\
\text { subjects and } \\
\text { dimensions measured } \\
\text { Subjects were allowed } \\
\text { to choose among the } \\
\text { tasks }\end{array}$ \\
\hline & & $\begin{array}{l}\text { - HF/high en (3.53 MJ) } \\
\text { - LCHO/low en (1.81 MJ) } \\
\text { - HCHO/high en (3.51 MJ) }\end{array}$ & $\begin{array}{l}\text { Assessment before and after } \\
\text { consuming the lunch }\end{array}$ & & $\begin{array}{l}\text { Unrestricted access to } \\
\text { caffeine and nicotine }\end{array}$ \\
\hline \multirow[t]{2}{*}{$\begin{array}{l}\text { Lloyd et al. } \\
\quad(1994)\end{array}$} & \multirow{2}{*}{$\begin{array}{l}\text { Eighteen subjects } \\
\text { (fifteen F, } \\
\text { three M), } \\
\text { mean age } \\
27 \text { years }\end{array}$} & $\begin{array}{l}\text { Three iso-caloric lunches } \\
\text { (about } 2.93 \mathrm{MJ}) \text { : }\end{array}$ & Bakan task (sustained attention) & \multirow[t]{2}{*}{$\begin{array}{l}\text { No effect on sustained } \\
\text { attention }\end{array}$} & \\
\hline & & $\begin{array}{l}\text { - LF/HCHO (2.90 MJ, } \\
29 / 54 \% \text { en) } \\
- \text { MF/MCHO (2.95 MJ, } \\
\text { 45/42\% en) } \\
\text { - HF/LCHO (3.01 MJ, } \\
\text { 62/24\% en) }\end{array}$ & $\begin{array}{l}\text { Assessment } 30 \text { min before } \\
\text { lunch, } 30 \mathrm{~min}, 90 \mathrm{~min} \text { and } \\
150 \mathrm{~min} \text { after finishing lunch }\end{array}$ & & \\
\hline
\end{tabular}




\begin{tabular}{|c|c|c|}
\hline $\begin{array}{l}\text { Smith et al. } \\
\text { (1994a) }\end{array}$ & $\begin{array}{l}\text { Forty-six } \\
\text { university } \\
\text { students } \\
\text { (twenty M, } \\
\text { twenty-six F) }\end{array}$ & $\begin{array}{l}\text { Four lunches: } \\
\text { - small HF: } 530 \mathrm{~g}, 5.40 \mathrm{MJ}, \\
55 \% \text { fat } \\
\text { - large HF: } 840 \mathrm{~g}, 5.44 \mathrm{MJ}, \\
\text { 58\% fat } \\
\text { - small LF: } 600 \mathrm{~g}, 3.51 \mathrm{MJ}, \\
\text { 19\% fat } \\
\text { - large LF: } 840 \mathrm{~g}, 3.68 \mathrm{MJ}, \\
\text { 23\% fat }\end{array}$ \\
\hline $\begin{array}{l}\text { Smith et al. } \\
\quad(1994 c)\end{array}$ & $\begin{array}{l}\text { Experiment 1: } \\
\text { forty-eight } \\
\text { university } \\
\text { students } \\
\text { (twenty-four M, } \\
\text { twenty-four F) }\end{array}$ & $\begin{array}{l}\text { Six conditions: } \\
\text { - no BK + decaffeinated coffee } \\
\text { - cereal toast BK (equivalent to } \\
\text { LF) + decaffeinated coffee } \\
\text { - cooked BK (equivalent to } \\
\text { HF) + decaffeinated coffee } \\
\text { - no BK + caffeinated coffee } \\
\text { - cereal toast BK (equivalent to } \\
\text { LF) + caffeinated coffee } \\
\text { - cooked BK (equivalent to } \\
\text { HF) + caffeinated coffee }\end{array}$ \\
\hline $\begin{array}{l}\text { Wells et al. } \\
\text { (1995) }\end{array}$ & $\begin{array}{l}\text { Experiment 1: } \\
\text { five males }\end{array}$ & $\begin{array}{l}\text { Two testing days with two } \\
\text { consecutive } 3 \mathrm{~h} \text { duodenal } \\
\text { infusions of: } \\
\text { - } 100 \mathrm{~g} \text { intralipid// followed by } \\
\text { isotonic saline }(9 \mathrm{~g} \mathrm{NaCl} / \mathrm{l}) \\
\text { - isotonic saline }(9 \mathrm{~g} \mathrm{NaCl} / \mathrm{l}) \\
\text { followed by } 100 \mathrm{~g} \text { intralipid// } \\
\text { (cross-over balanced design) }\end{array}$ \\
\hline & $\begin{array}{l}\text { Experiment 2: } \\
\text { eight males }\end{array}$ & $\begin{array}{l}\text { Fixed BK (3.18 MJ) and two iso- } \\
\text { energetic lunches (3.66 MJ): } \\
\text { - LF/HCHO }(7 / 76 \% \text { en) } \\
- \text { HF/LCHO }(64 / 18 \% \text { en })\end{array}$ \\
\hline $\begin{array}{l}\text { Wells \& } \\
\text { Read } \\
\text { (1996) }\end{array}$ & $\begin{array}{l}\text { Eighteen males } \\
\text { (groups } A \text { and } B: \\
\text { nine } M \text { in each) }\end{array}$ & $\begin{array}{l}\text { Two meals: } \\
\text { - HF/LCHO (3.18 MJ, } \\
55 / 40 \% \text { en) } \\
- \text { LF/HCHO (3.60 MJ, } \\
\text { 88/7\% en) } \\
\text { Group A: ate meals at } \\
10.30 \text { (brunch) } \\
\text { Group B: BK (08.15) and } \\
\text { test meal at } 12.30 \text { (lunch) }\end{array}$ \\
\hline $\begin{array}{l}\text { Lloyd et al. } \\
\text { (1996) }\end{array}$ & $\begin{array}{l}\text { Sixteen healthy habitual } \\
\text { BK eaters (fourteen F, } \\
\text { two M), age } 26 \text { years } \\
\text { Habitual BK ( } 1.05 \mathrm{MJ} \\
25 \% \text { fat, } 65 \% \mathrm{CHO})\end{array}$ & $\begin{array}{l}\text { Four conditions: } \\
\text { - no BK } \\
\text { - three iso-caloric BK (2.51 MJ): } \\
\text { - LF/HCHO }(27 / 62 \% \text { en }) \\
\text { - MF/MCHO }(44 / 47 \% \text { en }) \\
\text { - HF/LCHO }(56 / 34 \% \text { en })\end{array}$ \\
\hline $\begin{array}{l}\text { Lluch et al. } \\
\qquad(2000)\end{array}$ & $\begin{array}{l}\text { Thirty-two } \\
\text { volunteers } \\
\text { (sixteen M and } \\
\text { sixteen F; } \\
\text { seventeen LF } \\
\text { and fifteen HF } \\
\text { consumers) }\end{array}$ & $\begin{array}{l}\text { Two iso-caloric BK (1.72 MJ) and } \\
\text { lunches ( } 3.10 \mathrm{MJ} \text { for } \mathrm{F}, 4.14 \mathrm{MJ} \text { for } \\
\text { M): } \\
\text { - LF/HCHO (BK: } 22 / 67 \% \text { en, lunch: } \\
20 / 61 \% \text { en) } \\
-\mathrm{HF} / \mathrm{LCHO} \text { (BK: } 48 / 42 \% \text { en, lunch: } \\
54 / 32 \% \text { en) }\end{array}$ \\
\hline
\end{tabular}

Repeated digit vigilance task

Focused attention task

Assessment before lunch and

$90 \mathrm{~min}$ after the start of the meal No effect of fat content or weight

Slower but more accurate

response after HF lunch than

after LF lunch on selective

of the meals on vigilance tasks

Repeated-digits vigilance task

No effect of BK on performance on sustained attention tasks

Assessment $30 \mathrm{~min}$ before $\mathrm{BK}$, 60 and 120 min after the start of

$$
\text { BK }
$$

\section{Sustained attention task \\ Assessment at seven time \\ points: one before the first \\ infusion and six during the two}

infusions

Sustained attention task

Bakan task

\section{Bakan task}

Assessment beginning $30 \mathrm{~min}$

before, and $30 \mathrm{~min}, 90 \mathrm{~min}$ and

150 min after BK

Attention

Assessment just before and

$30 \mathrm{~min}$ after finishing lunch
Lipid affected the speed and accuracy of performance in the sustained attention task

Responses to stimuli in the sustained attention task slower after the HF than after the LF meal

Increase in the frequency of false alarms in the Bakan tes after the LF/HCHO brunch

\section{No clear difference in}

performance between the

four conditions

No effect on attention

No effect of habitual diet on

performance
Between-subjects design

Between-subject design
BK provided in the study was higher in energy than usual BK 
Table 3. Continued

\begin{tabular}{|c|c|c|c|c|c|}
\hline Reference & Sample & Study design & Cognitive testing & Results & Comments \\
\hline $\begin{array}{l}\text { Kanarek \& } \\
\text { Swinney } \\
\text { (1990) }\end{array}$ & $\begin{array}{l}\text { Experiment 2: } \\
\text { eight males }\end{array}$ & $\begin{array}{l}\text { Four conditions: BK (1.26 MJ) } \\
\text { followed by: } \\
\text { - lunch + caloric snack } \\
\text { (confectionary snack) } \\
\text { - no lunch + caloric snack } \\
\text { - lunch + non-caloric snack (drink) } \\
\text { - no lunch + non-caloric snack (drink) } \\
\text { Same conditions, but caloric snack } \\
\text { replaced by fruit-flavoured yoghurt }\end{array}$ & $\begin{array}{l}\text { Attention } \\
\text { Assessment } 15 \text { min following } \\
\text { eating of the snack } \\
\text { Subjects blind to caloric content } \\
\text { of snacks }\end{array}$ & $\begin{array}{l}\text { Subjects responded faster in the } \\
\text { attention task after the caloric } \\
\text { snack than after the non-caloric } \\
\text { snack }\end{array}$ & $\begin{array}{l}\text { Practice effects observed; } \\
\text { therefore, a practice } \\
\text { day introduced in the } \\
\text { second experiment } \\
\text { Pre-lunch performance } \\
\text { not assessed (in both } \\
\text { experiments) }\end{array}$ \\
\hline $\begin{array}{l}\text { Smith \& } \\
\quad \text { Miles } \\
(1986 a)\end{array}$ & $\begin{array}{l}\text { Forty-eight } \\
\text { university } \\
\text { students } \\
\text { (eighteen M, } \\
\text { thirty F) }\end{array}$ & $\begin{array}{l}\text { Two conditions: } \\
\text { - lunch (three-course meal } \\
\text { from university refectory, chosen } \\
\text { by subjects) } \\
\text { - no lunch }\end{array}$ & $\begin{array}{l}\text { Detection of repeated numbers } \\
\text { Assessment before and after } \\
\text { lunch }\end{array}$ & $\begin{array}{l}\text { Deficit in performance following } \\
\text { lunch consumption on number } \\
\text { task }\end{array}$ & $\begin{array}{l}\text { Caffeine also consumed } \\
\text { following lunch }\end{array}$ \\
\hline $\begin{array}{l}\text { Smith \& } \\
\text { Miles } \\
(1986 b)\end{array}$ & $\begin{array}{l}\text { Forty-eight } \\
\text { subjects }\end{array}$ & $\begin{array}{l}\text { Two conditions: } \\
\text { - lunch } \\
\text { - no lunch }\end{array}$ & $\begin{array}{l}\text { Stroop colour and word task } \\
\text { (selective attention) } \\
\text { Assessment before and after } \\
\text { lunch }\end{array}$ & Stroop not influenced by lunch & \\
\hline $\begin{array}{l}\text { Smith \& } \\
\text { Miles } \\
(1986 c)\end{array}$ & $\begin{array}{l}\text { Twenty-four } \\
\text { university } \\
\text { students }\end{array}$ & $\begin{array}{l}\text { Four conditions: } \\
\text { - lunch (soup, two sandwiches, } \\
\text { fruit pie and fruit) } \\
\text { - no lunch } \\
\text { - with or without noise } \\
\text { ( } 75 \mathrm{~dB} \text { v. } 40 \mathrm{~dB} \text { ) }\end{array}$ & Detection of odd or even digits & $\begin{array}{l}\text { Hit rate positively correlated with } \\
\text { extraversion, negatively correlated } \\
\text { with neuroticism } \\
\text { Post-lunch dip in hits detected and } \\
\text { RT in the } 40 \mathrm{~dB} \text { (quiet) but not } \\
75 \mathrm{~dB} \text { (noisy) condition }\end{array}$ & \\
\hline $\begin{array}{l}\text { Smith et al. } \\
\quad(1994 c)\end{array}$ & $\begin{array}{l}\text { Forty-eight } \\
\text { university } \\
\text { students } \\
\text { (twenty-four M, } \\
\text { twenty-four F) }\end{array}$ & $\begin{array}{l}\text { Four conditions: } \\
\text { - three-course meal } \\
(5 \cdot 02-6 \cdot 28 \mathrm{MJ})+ \\
\text { decaffeinated drink } \\
\text { - three-course meal } \\
(5 \cdot 02-6 \cdot 28 \mathrm{MJ})+ \\
\text { caffeinated drink } \\
\text { - no meal +decaffeinated } \\
\text { drink } \\
\text { - no meal + caffeinated } \\
\text { drink }\end{array}$ & $\begin{array}{l}\text { Repeated-digits vigilance } \\
\text { task } \\
\text { Assessment before the meal } \\
\text { and } 90 \mathrm{~min} \text { and } 180 \mathrm{~min} \text { after } \\
\text { the start of the meal }\end{array}$ & No effects on task & $\begin{array}{l}\text { Effects are different } \\
\text { from those observed } \\
\text { after lunch or BK }\end{array}$ \\
\hline $\begin{array}{l}\text { Fischer } \\
\text { et al. } \\
\text { (2001) }\end{array}$ & Fifteen young males & $\begin{array}{l}1670 \mathrm{~kJ} \text { at breakfast, } \\
\text { spoonable creams of: } \\
\text { - pure fat } \\
\text { - pure CHO } \\
\text { - pure protein }\end{array}$ & $\begin{array}{l}\text { Combi test (peripheral attention) } \\
\text { Hourly for } 3 \mathrm{~h} \text { post ingestion }\end{array}$ & $\begin{array}{l}\text { Best performance after fat } \\
\text { Protein better than } \mathrm{CHO} \\
\mathrm{CHO} \text { - more accurate } \\
\text { Protein - more efficient }\end{array}$ & \\
\hline
\end{tabular}

BK, breakfast; CHO, carbohydrate; DSST, digit symbol substitution test; en, energy; F, female; HCHO, high carbohydrate; HF, high fat; HP, high protein; LCHO, low carbohydrate; LF, low fat; M, male; MCHO, medium carbohydrate; MF, medium fat; RT, reaction time. 
Table 4. Effect of nutrients on memory tasks

\begin{tabular}{|c|c|c|c|c|c|c|}
\hline Reference & Sample & Study design & Cognitive testing & Results & Comments & \\
\hline $\begin{array}{l}\text { Deijen } \\
\quad \text { et al. } \\
\quad(1989)\end{array}$ & $\begin{array}{l}\text { Two groups: } \\
- \text { control }(n=9) \\
- \text { diet }(n=10) \\
21-27 \text { years }\end{array}$ & $\begin{array}{l}\text { During three weeks, } \\
\text { diet group had a daily intake } \\
\text { of } 110 \mathrm{~g} \text { protein, } 320 \mathrm{~g} \mathrm{CHO} \text {, } \\
80 \mathrm{~g} \text { fat } \\
\text { - BK: } 70 \mathrm{~g} \text { protein }(63 \%), \\
25 \mathrm{~g} \mathrm{CHO}(8 \%) \\
\text { - lunch: } 10 \mathrm{~g} \text { protein }(9 \%), \\
100 \mathrm{~g} \mathrm{CHO}(31 \%)\end{array}$ & $\begin{array}{l}\text { Pattern comparison } \\
\text { Memory scanning task } \\
\text { Assessment: baseline scores } \\
\text { (last day of } 3 \text { weeks, after } \\
\text { BK and dinner) and post- } \\
\text { treatment scores ( } 2 \text { months } \\
\text { later) }\end{array}$ & $\begin{array}{l}\text { Diet group performed more } \\
\text { slowly in the morning on } \\
\text { memory scanning task than } \\
\text { the control group }\end{array}$ & & \\
\hline $\begin{array}{l}\text { Markus } \\
\quad \text { et al. } \\
\quad(1998)\end{array}$ & $\begin{array}{l}\text { Forty-three subjects: } \\
\text { twenty-two HS, } \\
\text { twenty-one LS }\end{array}$ & $\begin{array}{l}\text { Two iso-energetic diets: } \\
\text { - CHO-rich, protein-poor diet } \\
\text { (66\% CHO, } 4 \% \text { protein, } \\
30 \% \text { fat) } \\
\text { - protein-rich/CHO-poor diet } \\
\text { ( } 40 \% \mathrm{CHO}, 26 \% \text { protein, } 33 \% \text { fat) }\end{array}$ & $\begin{array}{l}\text { Memory scanning task after } \\
\text { controllable or } \\
\text { uncontrollable stress }\end{array}$ & $\begin{array}{l}\text { Performance in HS subjects } \\
\text { was better with the CHO-rich } \\
\text { diet than with the protein-rich } \\
\text { diet, but only after controllable } \\
\text { stress }\end{array}$ & & \\
\hline $\begin{array}{l}\text { Deijen } \\
\quad \text { et al. } \\
\quad(1999)\end{array}$ & $\begin{array}{l}\text { Twenty-one cadets } \\
\text { (two groups, of ten } \\
\text { and eleven, receiving } \\
\text { two different drinks) }\end{array}$ & $\begin{array}{l}\text { Five daily doses of an } \\
\text { iso-caloric drink ( } 1.07 \mathrm{MJ}) \text { : } \\
\text { - protein-rich drink ( } 2 \mathrm{~g} \text { tyrosine) } \\
\text { - CHO-rich drink }\end{array}$ & $\begin{array}{l}\text { Memory task } \\
\text { Assessment before the } \\
\text { combat course and on the } \\
\text { sixth day of the course }\end{array}$ & $\begin{array}{l}\text { Group with the tyrosine-rich drink } \\
\text { performed better on a memory } \\
\text { task than the group consuming } \\
\text { the CHO-rich drink }\end{array}$ & Between-subjects design & $\underbrace{\varpi}_{2}$ \\
\hline $\begin{array}{l}\text { Benton } \\
\quad \text { et al. } \\
\quad(1994)\end{array}$ & $\begin{array}{l}\text { Seventy young female } \\
\text { students }\end{array}$ & $\begin{array}{l}\text { Glucose drink }(50 \mathrm{~g}) \text { after } \\
\text { baseline and } 25 \mathrm{~min} \text { later } \\
\text { ( } 25 \mathrm{~g} \text { ) or } \mathrm{CHO} \text {-free placebo } \\
\text { drinks (sweetened with } \\
\text { aspartame and acesulfame K) }\end{array}$ & Memory task & $\begin{array}{l}\text { Improved recall after glucose drink } \\
\text { No differential effect on primacy or } \\
\text { recency }\end{array}$ & $\begin{array}{l}\text { Between subjects design, no } \\
\text { dietary restrictions on test } \\
\text { day }\end{array}$ & 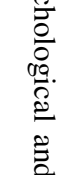 \\
\hline $\begin{array}{l}\text { Martin \& } \\
\text { Benton } \\
\text { (1999) }\end{array}$ & Eighty female students & $\begin{array}{l}\text { Four groups: } \\
-\mathrm{BK}+50 \mathrm{~g} \text { glucose drink }(n=28) \\
-\mathrm{BK}+\text { placebo drink }(n=25) \\
- \text { fasted }+50 \mathrm{~g} \text { glucose drink } \\
(n=12) \\
\text { - fasted }+ \text { placebo drink }(n=15)\end{array}$ & $\begin{array}{l}\text { Brown-Petersen memory } \\
\text { task }\end{array}$ & $\begin{array}{l}\text { Poorer performance after fasting } \\
\text { Glucose improved memory in } \\
\text { fasted subjects } \\
\text { BK consumption associated with } \\
\text { better memory } \\
\text { Rapidly falling blood glucose } \\
\text { associated with better memory }\end{array}$ & $\begin{array}{l}\text { Between subjects design } \\
\text { Nature of BK consumed not } \\
\text { known/controlled }\end{array}$ & 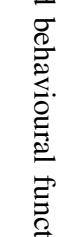 \\
\hline \multirow[t]{2}{*}{$\begin{array}{l}\text { Kelly et al. } \\
\text { (1994) }\end{array}$} & $\begin{array}{l}\text { Experiment 1: two } \\
\text { groups of six subjects }\end{array}$ & $\begin{array}{l}\text { Four lunches varying in energy } \\
\text { and fat and carbohydrate } \\
\text { content: } \\
\text { - LF/low en }(1.80 \mathrm{MJ}) \\
\text { - HF/high en }(3.53 \mathrm{MJ}) \\
\text { - LCHO/low en }(1.80 \mathrm{MJ}) \\
\text { - HCHO/high en }(3.51 \mathrm{MJ})\end{array}$ & $\begin{array}{l}\text { Number recognition task } \\
\text { Repeated acquisition task } \\
\text { Assessment before and after } \\
\text { consuming the lunch } \\
\text { (Experiment 1); after BK and } \\
\text { lunch (Experiment 2) }\end{array}$ & $\begin{array}{l}\text { In both experiments: } \\
\text { - performance on the tasks was } \\
\text { poorer after than before the } \\
\text { meal } \\
\text { - no systematic variations in } \\
\text { performance as a consequence } \\
\text { of either the energy or } \\
\text { macronutrient content of the meal }\end{array}$ & $\begin{array}{l}\text { Limited number of subjects } \\
\text { and dimension measured } \\
\text { Subjects were allowed to } \\
\text { choose among the tasks } \\
\text { Unrestricted access } \\
\text { to caffeine and nicotine }\end{array}$ & $\vec{\Xi}$. \\
\hline & $\begin{array}{l}\text { Experiment 2: two } \\
\text { groups of six subjects }\end{array}$ & $\begin{array}{l}\text { BK, lunch, afternoon snack } \\
\text { different in energy, fat and } \\
\text { CHO content: } \\
\text { - LF (3.09 MJ) } \\
\text { - MF (5.16 MJ) } \\
\text { - HF (7.05 MJ) } \\
\text { - LCHO (2.95 MJ) } \\
\text { - MCHO (5.08 MJ) } \\
\text { - HCHO (6.97 MJ) }\end{array}$ & & & & \\
\hline $\begin{array}{l}\text { Lloyd et al. } \\
\quad(1994)\end{array}$ & $\begin{array}{l}\text { Eighteen subjects } \\
\text { (fifteen } F \text {, three } M \text { ), } \\
\text { mean age } 27 \text { years }\end{array}$ & $\begin{array}{l}\text { Three iso-caloric lunches } \\
\text { (about } 2.93 \mathrm{MJ}): \\
\text { - LF/HCHO }(2.90 \mathrm{MJ}, 29 / 54 \% \text { en }) \\
\text { - MF/MCHO }(2.95 \mathrm{MJ}, 45 / 42 \% \text { en }) \\
\text { - HF/LCHO }(3.01 \mathrm{MJ}, 62 / 24 \% \text { en })\end{array}$ & $\begin{array}{l}\text { Free recall task (memory) } \\
\text { Assessment } 30 \text { min before } \\
\text { lunch, } 30 \text { min, } 90 \text { min and } \\
150 \text { min after finishing lunch }\end{array}$ & No effect on memory & & $\stackrel{N}{\stackrel{N}{O}}$ \\
\hline
\end{tabular}




\begin{tabular}{|c|c|c|c|c|c|}
\hline Reference & Sample & Study design & Cognitive testing & Results & Comments \\
\hline $\begin{array}{l}\text { Smith } \\
\quad \text { et al. } \\
\text { (1994) }\end{array}$ & $\begin{array}{l}\text { Experiment 2: } \\
\text { forty-eight } \\
\text { university } \\
\text { students } \\
\text { (twenty-four M, } \\
\text { twenty-four F) }\end{array}$ & $\begin{array}{l}\text { Four conditions: } \\
\text { - no BK + decaffeinated coffee } \\
\text { - cooked BK (equivalent to } \\
\text { HF) + decaffeinated coffee } \\
\text { - no BK + caffeinated coffee } \\
\text { - cooked BK (equivalent to } \\
\text { HF) + caffeinated coffee }\end{array}$ & $\begin{array}{l}\text { Four memory tasks: } \\
\text { - free recall } \\
\text { - delayed recognition memory } \\
\text { - logical reasoning } \\
\text { - semantic reasoning } \\
\text { Assessment } 60 \text { min before } \\
\text { BK, } 45 \text { and } 105 \text { min after the } \\
\text { start of BK }\end{array}$ & $\begin{array}{l}\text { BK improved performance on } \\
\text { free recall and delayed } \\
\text { recognition memory tasks } \\
\text { No effect on semantic memory } \\
\text { task } \\
\text { Impairment of the accuracy of } \\
\text { performing the logical } \\
\text { reasoning task }\end{array}$ & $\begin{array}{l}\text { Between-subjects design } \\
\text { Conclusions about the } \\
\text { effects of BK on } \\
\text { performance } \\
\text { depend on the type of } \\
\text { task }\end{array}$ \\
\hline $\begin{array}{l}\text { Lloyd et al. } \\
\quad(1996)\end{array}$ & $\begin{array}{l}\text { Sixteen healthy habitual } \\
\text { BK eaters (fourteen F, } \\
\text { two M), age } 26 \text { years } \\
\text { Habitual BK (1.05 MJ, } \\
25 \% \text { fat, } 65 \% \mathrm{CHO})\end{array}$ & $\begin{array}{l}\text { Four conditions: } \\
\text { - no BK } \\
\text { - three iso-caloric BK }(2 \cdot 51 \mathrm{MJ}) \\
\text { - LF/HCHO }(27 / 62 \% \text { en }) \\
\text { - MF/MCHO }(44 / 47 \% \text { en }) \\
\text { - HF/LCHO }(56 / 34 \% \text { en })\end{array}$ & $\begin{array}{l}\text { Free recall task } \\
\text { Assessment beginning } 30 \mathrm{~min} \\
\text { before, and } 30 \mathrm{~min}, 90 \mathrm{~min} \\
\text { and } 150 \mathrm{~min} \text { after } \mathrm{BK}\end{array}$ & $\begin{array}{l}\text { No clear difference in } \\
\text { performance between the } \\
\text { four conditions }\end{array}$ & $\begin{array}{l}\text { BK provided in the study } \\
\text { was higher in energy than } \\
\text { usual BK }\end{array}$ \\
\hline $\begin{array}{l}\text { Lluch et al. } \\
\qquad(2000)\end{array}$ & $\begin{array}{l}\text { Thirty-two volunteers } \\
\text { (sixteen M and sixteen F; } \\
\text { seventeen LF and fifteen } \\
\text { HF consumers) }\end{array}$ & $\begin{array}{l}\text { Two iso-caloric BK }(1.72 \mathrm{MJ}) \text { and } \\
\text { lunches (3.10 MJ for F, } 4.14 \mathrm{MJ} \\
\text { for M): } \\
\text { - LF/HCHO (BK: } 22 / 67 \% \text { en, } \\
\text { lunch: } 20 / 61 \% \text { en) } \\
\text { - HF/LCHO (BK: } 48 / 42 \% \text { en, } \\
\text { lunch: } 54 / 32 \% \text { en) }\end{array}$ & $\begin{array}{l}\text { Associative memory (code } \\
\text { substitution) } \\
\text { Assessment just before and } \\
30 \text { min after finishing lunch }\end{array}$ & $\begin{array}{l}\text { No effect on memory task } \\
\text { No effect of habitual diet on } \\
\text { performance }\end{array}$ & \\
\hline $\begin{array}{l}\text { Kanarek \& } \\
\text { Swinney } \\
\text { (1990) }\end{array}$ & $\begin{array}{l}\text { Experiment 1: sixteen } \\
\text { males (19-22 years) }\end{array}$ & $\begin{array}{l}\text { Four conditions: BK ( } 1 \cdot 26 \mathrm{MJ}) \\
\quad \text { followed by: } \\
\text { - lunch + caloric snack } \\
\text { (confectionary snack) } \\
\text { - no lunch + caloric snack } \\
\text { - lunch + non-caloric - snack (drink) } \\
\text { - no lunch + non-caloric snack (drink) }\end{array}$ & $\begin{array}{l}\text { Digit span recall (forwards } \\
\text { and backwards) } \\
\text { Assessment } 15 \text { min following } \\
\text { eating of the snack }\end{array}$ & $\begin{array}{l}\text { Subjects recalled more digits } \\
\text { in the backwards digit span } \\
\text { test after the caloric snack } \\
\text { than after the non-caloric } \\
\text { snack }\end{array}$ & $\begin{array}{l}\text { Practice effects observed } \\
\text { Pre-lunch performance not } \\
\text { assessed (in both } \\
\text { experiments) }\end{array}$ \\
\hline $\begin{array}{l}\text { Parker \& } \\
\text { Benton } \\
\text { (1995) }\end{array}$ & $\begin{array}{l}\text { Thirty-three university } \\
\text { students } \\
\text { (seventeen M, } \\
\text { sixteen F), mean age } \\
21 \text { years }\end{array}$ & $\begin{array}{l}\text { Two conditions: } \\
\text { - no BK } \\
\text { - milk-based nutritional } \\
\text { beverage }\end{array}$ & $\begin{array}{l}\text { Spatial memory } \\
\text { Immediate recall } \\
\text { Assessment } 2 \mathrm{~h} \text { after BK }\end{array}$ & $\begin{array}{l}\text { Subjects who ate a BK took } \\
\text { less time to finish memory } \\
\text { tasks than subjects who did } \\
\text { not have BK } \\
\text { No effect of BK on number of } \\
\text { errors }\end{array}$ & Between-subjects design \\
\hline $\begin{array}{l}\text { Smith } \\
\quad \text { et al. } \\
\quad(1994 c)\end{array}$ & $\begin{array}{l}\text { Forty-eight students } \\
\text { (twenty-four M, } \\
\text { twenty-four F) }\end{array}$ & $\begin{array}{l}\text { Four conditions: } \\
\text { - three-course meal }(5.02- \\
6 \cdot 28 \mathrm{MJ})+ \text { decaffeinated drink } \\
\text { - three-course meal }(5 \cdot 02- \\
6.28 \mathrm{MJ})+ \text { caffeinated drink } \\
\text { - no meal + decaffeinated drink } \\
\text { - no meal + caffeinated drink }\end{array}$ & $\begin{array}{l}\text { Free recall task } \\
\text { Delayed recognition memory } \\
\text { task } \\
\text { Assessment before the meal } \\
\text { and } 90 \mathrm{~min} \text { and } 180 \mathrm{~min} \text { after } \\
\text { the start of the meal }\end{array}$ & No effects on memory tasks & $\begin{array}{l}\text { Effects are different from } \\
\text { those observed after } \\
\text { lunch or BK }\end{array}$ \\
\hline $\begin{array}{l}\text { Smith } \\
\text { et al. } \\
\text { (1999) }\end{array}$ & $\begin{array}{l}144 \text { volunteers } \\
\text { (seventy-two M, } \\
\text { seventy-two F), } \\
\text { mean age } 21 \text { years }\end{array}$ & $\begin{array}{l}\text { Four conditions: } \\
\text { - no BK + decaffeinated coffee } \\
\text { - no BK + caffeinated coffee } \\
\text { - cereal BK + decaffeinated coffee } \\
\text { - cereal BK + caffeinated coffee }\end{array}$ & $\begin{array}{l}\text { Spatial memory task } \\
\text { Working memory } \\
\text { Assessment before BK, } \\
60 \text { min and } 120 \text { min after } \\
\text { the beginning of BK }\end{array}$ & $\begin{array}{l}\text { Subjects who consumed the } \\
\text { cereal BK performed better } \\
\text { on the spatial memory task } \\
\text { than those in the no BK } \\
\text { condition }\end{array}$ & Between-subjects design \\
\hline
\end{tabular}

BK, breakfast; $\mathrm{CHO}$, carbohydrate; en, energy; F, female; HCHO, high carbohydrate; HF, high fat; HP, high protein; HS, high-stress-prone; LCHO, low carbohydrate; LF, low fat; LS, low-stress-prone; M, male; $\mathrm{MCHO}$ medium carbohydrate; $\mathrm{MF}$, medium fat. 
(Hassmen et al. 1994). Since exercise increases the plasma concentration ratio of free tryptophan to other large neutral amino acids leading to an elevation of 5-HT in the brain, branched-chain amino acids may therefore minimise central and mental fatigue during and after sustained exercise.

\section{Interim summary for cognitive performance}

In summary, acute interventions with high carbohydrate and low protein are sedating and anxiolytic. Protein-rich, carbohydrate-poor interventions tend to produce arousal and improve reaction time and vigilance. Nutritional interventions that facilitate a rise in blood glucose enhance performance of memory and reaction time tasks. The decline in glucose in hypoglycaemia impairs performance. Fat appears to decrease alertness but this effect is often delayed and the habitual diet is important in producing this response. Acute effects vary with time of day. The effect size for glucose is larger than for other macronutrient manipulations and confounding variables are more easily controlled. Chronic or longer-term intervention studies are rarer but suggest that a protein-rich diet can increase negative and decrease positive affect. Longer-term (habitual diet) effects on performance are important because of their relationship to certain disease states that carry with them the risk of cognitive impairment. Poor glucose regulation is associated with poor cognitive performance although this has been examined only in healthy elderly (Kaplan et al. 2000) and diabetic (Strachan et al. 1997) populations.

\section{Biomarkers for cognitive performance}

Biomarkers for cognitive function are probably more difficult to measure than the actual function itself. We are currently lacking a strong theoretical base to relate neurochemical or physiological activity to cognitive performance. Biomarkers need to be identified in order to elucidate the mechanisms by which food components may affect performance. However, these mechanisms are unlikely to be simple and therefore biomarkers are not an easy route to identifying the effects of food on specific functions.

It is also clear that cognitive performance is normally well protected by a regulatory process that maintains a stable output. This means that effectiveness of overt task behaviour is difficult to disrupt or enhance but the cost of maintaining efficient processing and performance capacity may vary. Decrements are therefore difficult to measure except in circumstances where large manipulations or interventions have an effect on control mechanisms, e.g. drugs with strong effects on the central nervous system. Any genuine effects will tend to be subtle ones, and can only be detected reliably by measuring both overt performance and the underlying 'maintenance costs' of performance protection. These should be detectable as 'latent decrements' - various markers of increased regulatory strain — seen, for example, in sympathetic dominance in the autonomic nervous system, subjective strain (increased effort, strain, fatigue as after-effect) and in impairment in secondary aspects of performance in complex tasks where only the primary component is usually protected. In this case a measure of increased selectivity (narrowed attention) can be derived based on the relative performance in the primary and secondary tasks. Decrements should also be revealed by the use of tasks in which upper control is a key factor, e.g. as used to assess frontal lobe problems or fatigue after-effects (involving effort, planning, sequential management). Thus any assessment of cognitive performance should include measures of costs as well as of overt performance, and assess both upper and lower function (Hockey, 1997). One solution might be to build a complex task from simpler components, allowing one to test effects of cognitive components alone (i.e. minimal control) and also combined (with additional control requirement to manage the two and plan shifts of focus between them). These behavioural actions can be regarded as biological activities although they clearly differ from a physiological index such as blood glucose.

There are also some physiological indices that may be good candidates as biomarkers of cognitive function. These include measures of autonomic nervous system activity, heart rate and electroencephalography, although these are complex, variable and, currently, difficult to work with in experimental settings where cognitive performance is examined simultaneously. Blood glucose level or rate of change has been used as a biomarker in a number of studies. However, the action of glucose on the cholinergic system may increase synthesis of acetylcholine (Owens \& Benton, 1994). Hence the performance-enhancing effects of glucose on reaction time may not be solely related to the increased availability of neural fuel. Alternatively the effect may be produced by increased glucose uptake in the frontal cortex in response to cognitive load. The increase in heart rate associated with high cognitive load supports this assertion. Other studies suggest that stable performance is related to a balanced glucose metabolism and state of metabolic activation. Future markers might include metabolites of neurotransmitters, e.g. 5$\mathrm{HT}$, but the development of these will require an understanding of their involvement in simple and complex cognitive activities. Moreover, the use of physiological biomarkers relies on the assumption that peripheral measures reflect central activity.

\section{Functional foods for mood}

\section{Effect of food on mood and mood on performance}

There are some well-documented effects of food on mood and of mood on performance (for a review, see Rogers et al. 1995). Many studies have related the effects of food on mood to the modulation of serotonin by carbohydrate (e.g. Wurtman et al. 1981) but effects of consuming other foods on mood have also been documented, e.g. chocolate's positive effects on mood have been attributed to its orosensory properties (Macdiarmid \& Hetherington, 1995). Carbohydrate produces a reduction in depression in vulnerable samples such as premenstrually depressed women and those with seasonal affective disorder (Wurtman 
Table 5. Effect of nutrients on other tasks

\begin{tabular}{|c|c|c|}
\hline Reference & Sample & Study design \\
\hline $\begin{array}{l}\text { Deijen } \\
\text { et al. } \\
\text { (1989) }\end{array}$ & $\begin{array}{l}\text { Two groups: } \\
\text { - control }(n=9) \\
\text { - diet }(n=10) \\
21-27 \text { years }\end{array}$ & $\begin{array}{l}\text { During three weeks, diet group } \\
\text { had a daily intake of } 110 \mathrm{~g} \text { protein, } \\
320 \mathrm{~g} \mathrm{CHO}, 80 \mathrm{~g} \text { fat } \\
- \text { BK: } 70 \mathrm{~g} \text { protein }(63 \%), 25 \mathrm{~g} \\
\text { CHO }(8 \%) \\
\text { - lunch: } 10 \mathrm{~g} \text { protein }(9 \%), \\
100 \mathrm{~g} \mathrm{CHO}(31 \%)\end{array}$ \\
\hline $\begin{array}{l}\text { Deijen } \\
\quad \text { et al. } \\
\text { (1999) }\end{array}$ & $\begin{array}{l}\text { Twenty-one cadets } \\
\text { (two groups, of ten and } \\
\text { eleven, receiving two } \\
\text { different drinks) }\end{array}$ & $\begin{array}{l}\text { Five daily doses of an } \\
\text { iso-caloric drink }(1.07 \mathrm{MJ}) \text { : } \\
\text { - protein-rich drink ( } 2 \mathrm{~g} \text { tyrosine) } \\
\text { - CHO-rich drink }\end{array}$ \\
\hline \multirow[t]{2}{*}{$\begin{array}{l}\text { Kelly } \\
\quad \text { et al. } \\
\text { (1994) }\end{array}$} & $\begin{array}{l}\text { Experiment 1: two } \\
\text { groups of six subjects }\end{array}$ & $\begin{array}{l}\text { Four lunches varying in energy } \\
\text { and fat and CHO content: } \\
\text { - LF/low en }(1.80 \mathrm{MJ}) \\
\text { - HF/high en }(3.53 \mathrm{MJ}) \\
- \text { LCHO/low en }(1.81 \mathrm{MJ}) \\
-\mathrm{HCHO} / \mathrm{high} \text { en }(3.51 \mathrm{MJ})\end{array}$ \\
\hline & $\begin{array}{l}\text { Experiment 2: two } \\
\text { groups of six subjects }\end{array}$ & $\begin{array}{l}\text { BK, lunch, afternoon snack } \\
\text { different in energy, fat and } \\
\text { CHO content: } \\
\text { - LF (3.09 MJ) } \\
\text { - MF }(5.16 \mathrm{MJ}) \\
\text { - HF }(7.05 \mathrm{MJ}) \\
\text { - LCHO }(2.94 \mathrm{MJ}) \\
\text { - MCHO }(5.06 \mathrm{MJ}) \\
\text { - HCHO }(6.97 \mathrm{MJ})\end{array}$ \\
\hline $\begin{array}{l}\text { Lloyd } \\
\text { et al. } \\
\text { (1994) }\end{array}$ & $\begin{array}{l}\text { Eighteen subjects } \\
\text { (fifteen } \mathrm{F} \text {, three } \mathrm{M} \text { ), } \\
\text { mean age } 27 \text { years }\end{array}$ & $\begin{array}{l}\text { Three iso-caloric lunches } \\
\text { (about } 2.93 \mathrm{MJ}) \\
\text { - LF/HCHO }(2.90 \mathrm{MJ}, 29 / 54 \% \text { en) } \\
\text { - MF/MCHO }(2.95 \mathrm{MJ}, 45 / 42 \% \text { en }) \\
\text { - HF/LCHO }(3.10 \mathrm{MJ}, 62 / 24 \% \text { en) }\end{array}$ \\
\hline $\begin{array}{l}\text { Cunliffe } \\
\text { et al. } \\
\text { (1997) }\end{array}$ & $\begin{array}{l}\text { Sixteen healthy } \\
\text { volunteers (nine M, } \\
\text { seven F), age } \\
20-47 \text { years } \\
\text { (mean, } 29.7 \text { years) }\end{array}$ & $\begin{array}{l}1672 \mathrm{~kJ} \text { at } \mathrm{BK} \text { approx. } 200 \mathrm{ml}: \\
\text { - pure } \mathrm{CHO} \text { (maltodextrin) } \\
\text { - pure fat (long chain triacylglycerol } \\
\text { emulsion) } \\
\text { Control: mixed } \mathrm{CHO} \text {, fat and protein } \\
\text { ( } 55 \% \mathrm{CHO}, 15 \% \text { protein, } 30 \% \text { fat } \\
\text { same sources of } \mathrm{CHO} \text { and fat) }\end{array}$ \\
\hline $\begin{array}{l}\text { Lloyd } \\
\text { et al. } \\
\text { (1996) }\end{array}$ & $\begin{array}{l}\text { Sixteen healthy habitual } \\
\text { BK eaters (fourteen F, } \\
\text { two M), age } 26 \text { years } \\
\text { Habitual BK ( } 1.05 \mathrm{MJ} \\
25 \% \text { fat, } 65 \% \mathrm{CHO})\end{array}$ & $\begin{array}{l}\text { Four conditions: } \\
\text { - no BK } \\
\text { - three iso-caloric BK }(2 \cdot 51 \mathrm{MJ}) \\
\text { - LF/HCHO }(27 / 62 \% \text { en }) \\
\text { - MF/MCHO }(44 / 47 \% \text { en }) \\
\text { - HF/LCHO }(56 / 34 \% \text { en })\end{array}$ \\
\hline
\end{tabular}

Cognitive testing

Finger tapping

Assessment: baseline scores

(last day of 3 weeks, after BK

and dinner) and post-treatment

scores (2 months later)

Tracking task

Assessment before the combat course and on the sixth day

of the course

Choice of four psychomotor

tasks available:

differential reinforcement of low-rate schedule of poin presentation

Assessment before and after

consuming the lunch

(Experiment 1); after BK

and lunch (Experiment 2)

Two-finger tapping task

Assessment $30 \mathrm{~min}$ before

unch, $30 \mathrm{~min}, 90 \mathrm{~min}$ and

150 min after finishing lunch

CFFT

Hourly for $4 \mathrm{~h}$ post ingestion

Two-finger tapping task

Assessment beginning $30 \mathrm{~min}$

before, and $30 \mathrm{~min}, 90 \mathrm{~min}$ and

150 min after BK
Results

Comments

Diet group performed better in the morning

on finger tapping than the control group

Group with the tyrosine-rich drink

performed better on tracking task

than the group consuming the

CHO-rich drink

In both experiments:

- performance on the tasks was poorer

after than before the meal

- no systematic variations in performance

as a consequence of either the energy
or macronutrient content of the meals

Between-subjects

design

Limited number of subjects and dimension

measured
Subjects were

Subjects were
allowed to choose among the tasks

Unrestricted access to caffeine and

nicotine
Reduced after $\mathrm{CHO}$ and fat
No clear difference in performance between the four conditions

BK provided in the study was higher in energy than 


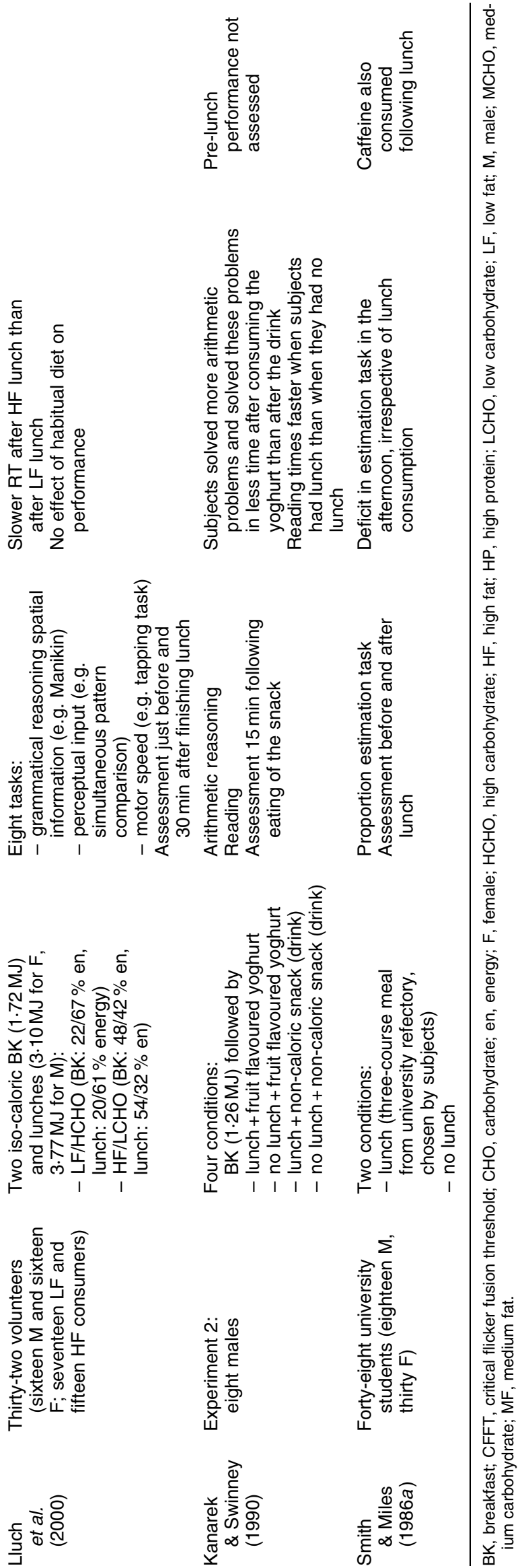

et al. 1989). Carbohydrate has also been shown to increase feelings of sedation and fatigue (see Reid \& Hammersley, 1995 for a review of the effects of carbohydrate). These studies have not, however, considered the mediating effect of mood on performance but rather have viewed a change in mood as a result of food intake as separate from any effects observed on performance. For instance, poorer performance has been observed in samples of highly restrained women or those currently dieting (Rogers \& Green, 1993; Green et al. 1994b; Green \& Rogers, 1995; Wing et al. 1995). Negative mood is also present in such samples and it is difficult to untangle the effects of dieting on performance from the effects of mood. Indeed the presence of both may compound effects.

Most studies in this area have considered mood to be a dependent variable rather than a predictor of level of performance. However, mood can affect performance in its own right and can modulate the motivation to perform well, affecting compensatory effort and reducing the effect of other interventions on overall level of performance. The effect of mood on performance is modulated by time of day, consumption of foods and stimulants such as caffeine, and can be influenced by mood-induction techniques. Exercise can also have positive effects on mood, which may interact with food consumed. Thus it is important to examine changes in subjective state after nutritional intervention and with a degree of statistical complexity relate these changes to effects on cognitive function, to determine whether mood change is a correlate or a consequence of the food ingested and the level of cognitive function demonstrated.

\section{Effect of mood on satiety}

Most of the studies examining the relationship between mood and eating behaviour tend to focus on the effects of food intake on mood (e.g. sleep and arousal) rather than the converse (i.e. the effects of mood on food intake). In fact, most of the work concerns the effects of dietary carbohydrate on serotonin, which tends to modulate mood (Wurtman \& Wurtman, 1989). The effects of manipulations on the macronutrient content of foods and diets have been discussed elsewhere (for a review see Benton \& Donohoe, 1999). Some subjective feelings and mood changes reported post ingestion in studies of performance can be related to the satiating and thermogenic effects of particular macronutrients, e.g. feelings of coldness or fullness which decrease and increase, respectively, after protein ingestion (Cunliffe et al. 1997; Fischer et al. 2001). When examining the effects of mood on food, most studies have been involved with how mood initiates and stimulates food intake (e.g. negative mood induces consumption of 'comfort' foods). Therefore, there is evidence to suggest that mood (in particular negative mood) may act as a precursor for food intake (i.e. initiation of a single eating episode) and possibly over-consumption of highly palatable foods (e.g. chocolate). However, the effects of mood on satiation and satiety are still undetermined, but it is likely that mood interacts with palatability to influence satiety. 


\section{Palatability}

The precise relationship between palatability (often regarded as the hedonic dimension of food) and appetite has been debated for some time now (Ramirez, 1990). The original work of Hill and colleagues (Hill et al. 1984) was instrumental in raising the issue by demonstrating that subjective hunger was higher after a preferred, fixed preload compared with a non-preferred, fixed preload. Therefore, it has been proposed that palatability has an important influence on the initiation and termination of eating events (Blundell \& Rogers, 1991b). The palatability of a food is as a result of the integration of orosensory and post-ingestive stimuli. Like hunger, palatability is a hypothetical construct; that is, an explanatory concept that cannot be observed directly itself, but is inferred from operationally defined and measurable events (Blundell \& Rogers, 1991a,b). Therefore, the term 'palatability', like hunger, can be conceived of in two ways: either as an intervening variable not measurable directly or, when construed as the perceived pleasantness of food, as a subjective experience that can be monitored objectively by means of a rating. Consequently, in reference to human appetite, palatability appears to be considered to be equivalent to perceived pleasantness of food. Nonetheless, the relationship of pleasantness (or palatability) to actual consumption remains to be determined. With reference to the mediating processes involved in the satiety cascade, it is important to know how these mechanisms are related to fluctuations in perceived palatability and hunger. For example, is high palatability a sufficient or necessary condition for the initiation of eating? It is suggested that the answer to both situations must be no, since there are occasions when even highly palatable food will not be consumed and unpalatable food will be consumed. Another important issue here is what is the relationship between palatability and the termination of eating (satiation)? That is, what is the relationship between palatability and hunger? It is known that mood has a strong influence on cognitive performance; therefore, the relationship amongst mood, satiety, palatability and performance is important.

\section{Effect of palatability on satiety}

Work on the relationship between palatability and satiety has demonstrated that hunger was increased at the end of a preferred meal compared with a non-preferred meal (Hill et al. 1984). This phenomenon has recently been confirmed (Yeomans, 1996; Yeomans et al. 1999). Moreover, with respect to the profile of hunger during eating, there was a tendency for hunger to increase during the early stages of eating when the most palatable food was consumed whereas fullness did not follow the same pattern. Therefore, these data suggest that the manipulation of palatability leads to stimulation of appetite, which in turn could increase food intake through the process of satiation. What is less clear is how palatability affects subsequent hunger and food intake (i.e. satiety). From the data that exist there seems to be some ambiguity about the effects of palatability on satiation and satiety (Hill et al. 1984; Johnson \& Vickers, 1992; Rogers \& Schutz, 1992; De Graaf et al. 1999).

\section{Effect of palatability on performance}

Whilst the relationship between palatability and food intake has been examined in many studies, the relationship between palatability and cognitive performance has not. In fact, our search has not identified any studies that have measured directly the effects of palatability per se on cognitive performance. It is, however, logical that palatability could influence cognitive performance via the mediating effects of mood (e.g. palatable food-induced increase in endorphins). That is, if an increase in palatability causes an increase in positive mood, then performance could also be enhanced. Despite the lack of evidence on this topic, some experiments intended to examine the effects of foods (e.g. macronutrient content, energy value, energy density) on cognitive performance have inadvertently allowed taste or palatability characteristics to vary.

\section{Habitual diet}

The composition of the habitual diet could have important consequences for the physiological and behavioural patterns of the participant. For example, phenotypes of habitual diet composition (low-fat $v$. high-fat) have recently been identified using data from a national database (Macdiarmid et al. 1996). It has been suggested that individuals habitually consuming different diets vary in certain physiological and behavioural characteristics (Blundell \& Cooling, 2000). Therefore, habitual diet may have an important influence on the effect of food on satiety, cognitive performance and mood as well as sleep (LeNoury et al. 2000).

\section{Habitual diet and satiety}

In line with the habitual diet composition, the familiarity with the preload could also have an important influence on the outcome. The effects of the interventions in the macronutrient (and energy) content of the food/diet on appetite control and performance may be dependent on the habitual diet of the participant. For example, a high-fat preload may have a different effect on a habitual, high-fat consumer compared with a habitual low-fat consumer (e.g. perceptions of palatability). Tournier \& Louis-Sylvestre (1991) have hypothesised that a learned adjustment to the calories in liquid food would occur with repeated exposure. One study demonstrated that informed and uninformed subjects ate similar weights of low- and high-energy sweet preloads (Rolls et al. 1989). This suggests that, when ingesting familiar foods, individuals may rely on previous experiences with these foods to determine how much they should eat (Booth et al. 1982). Clearly participants would not be able to do this with unfamiliar foods.

\section{Habitual diet and performance}

Habitual diet does not seem to influence performance in short-term studies where nutritional interventions are made (Lluch et al. 2000). However, performance seems to be optimal when the food consumed most resembles the usual diet, e.g. medium-fat, medium-carbohydrate (Lloyd et al. 1994, 1996). Naturalistic studies do, however, 
suggest that the habitual diet, which influences parameters such as cholesterol level, may influence levels of performance. Low plasma cholesterol was associated with slower movement and decision time on a choice reaction time task (Benton, 1995; Muldoon et al. 1997). However, this linear relationship was found only in females; males exhibited a non-linear relationship, suggesting that more than one mechanism may be involved. The interaction of habitual diet and cognitive performance in man requires further investigation. There may be an interaction between cholesterol, dieting and cognitive function because dieting lowers cholesterol.

Evidence from animal studies suggests that there may be differences between the chronic and acute impact of diets varying in fat content. Studies in animals suggest that the structure of the brain may be modified over time by dietary fatty acids (Wainwright et al. 1994). A highfat diet generally disrupts cognitive function. In addition, an enriched environment reduced the learning impairment associated with frontal lobe function whereas glucose enhanced memory performance by exerting beneficial effects on hippocampus-related memory function (Greenwood \& Winocur, 1997).

Some physical illnesses are associated with impairment of cognitive function and dietary intake is a risk factor for the development of these conditions, e.g. atherosclerosis, type 2 diabetes and hypertension. Obesity is a significant risk factor in the development of all these conditions. Rogers (2001) has reviewed the long-term impact of diet on mood and cognitive function in relation to these conditions. Antioxidants, vitamins and other nutritional supplements have been reported to prevent or delay agerelated cognitive impairment (Kalmijn et al. 1997; Lethem \& Orrell, 1997). Epidemiological studies support these findings (e.g. Gale et al. 1996) although some controlled studies have shown little or no effect of supplementation (Smith et al. 1999, 2000; Cockle et al. 2000).

\section{Summary}

This domain of research possesses great potential for collaborations between academia and industry for the development of such products with functional properties. The current world-wide epidemic of obesity has generated an urgent need for the development of functional foods with the capacity to control appetite and influence the regulation of body weight. Some foods already exist and others are under development. There is a clear market need for such products. At the same time, the requirement of foods to produce vitality and influence dynamic lifestyles creates a drive to produce foods with the capacity to empower people to cope well with an ever more challenging technological environment.

The physiological system underlying the function of satiety is better understood than that responsible for competitive performance. Key sites in the brain - and the periphery - have been identified, and both genetic and pharmaceutical tools have contributed to understanding the network. Consequently, some clear targets (and processes) exist to guide the development of functional foods for satiety. In the field of cognitions, rather less is known about the detail of the neural network although developments in pharmaceuticals have identified certain neurochemical systems and receptors. However, it is likely to be more difficult to develop foods that can exert specific and selective actions at such critically localised targets. Moreover, because of the importance of maintaining an adequate level of cognitive performance, people can protect themselves from degradation in performance by increasing effort. Consequently, measurement of both applied effort and the performance endpoint are required to assess the impact of nutritional manipulations.

A corollary of this is that, because of the requirement to maintain a continuous high level of cognitive performance, it is rather difficult for foods to enhance performance even further (the ceiling effect). Therefore, an appropriate strategy for foods may be to develop products that can protect people from an enforced performance decrement due to fatigue or stress.

Another strategic issue concerns the unavoidable simultaneous effect of foods on different domains of psychological behavioural functioning. In the field of pharmaceuticals it is well known that drugs developed for the treatment of one psychological condition - for example, anxiety can have collateral effects on appetite and satiety. The capacity of some anxiolytic and neuroleptic drugs to increase eating and body weight may contribute to a form of iatrogenic-induced obesity. In the field of functional foods it is therefore important to develop foods that enhance satiety without exerting detrimental effects on mood or cognitive performance; and to create more products for sustaining cognitive performance that do not compromise satiety.

A further challenge in this area is also to go beyond unitary cognitive functions to complete integrated performance relevant to modern life-styles such as vehicle driving, technological monitoring and operating industrial equipment. Only a very few studies (e.g. Moser et al. 1983) have examined the effects of food materials on a complicated skill such as car driving. This type of cognitive task clearly requires the interpretation of a number of cognitive functions such as reaction time, perceptual ability, information processing, tracking ability and memory.

The identification of biomarkers in the field of psychological and behavioural functions requires more thought and careful consideration. A biomarker can be conceptualised as an indicator of normal biological processes, a parameter associated with the psychological/ behavioural response or a surrogate endpoint. In other areas of physiological functioning relevant to functional foods, a convenient biomarker could be a measured variable in blood or some other tissue that correlated with a functional endpoint or disease state. A good example could be a measure of intestinal flora for bowel disease. However, in this particular field it may be more difficult to measure some underlying physiological or neural variable than it is to measure the functional endpoint itself. For both satiety and cognitive performance we have suggested how the issue of biomakers could be approached. 


\section{Acknowledgements}

The authors thank Orkla Foods A.S. for support with the scientific material for this review, and Susan Alexander for assistance with the manuscript.

\section{References}

Astrup A \& Flatt JP (1996) Metabolic determinants of body weight regulation. In Regulation of Body Weight: Biological and Behavioral Mechanisms, pp. 193-210 [C Bouchard and GA Bray, editors]. Chichester: John Wiley.

Bellisle F, Blundell JE, Dye L, Fantino M, Fern E, Fletcher RJ, Lambert J, Roberfroid M, Specter S, Westenhöfer J \& Westerterp-Plantenga MS (1998) Functional food science and behaviour and psychological functions. British Journal of Nutrition 80, S173-S193.

Benton D (1995) Do low cholesterol levels slow mental processing? Psychosomatic Medicine 57, 50-56.

Benton D \& Donohoe RT (1999) The effects of nutrients on mood. Public Health Nutrition 2, 403-409.

Benton D, Owens D \& Parker P (1994) Blood glucose memory and attention. Neuropsychologia 115, 129.

Blundell JE (1991) Pharmacological approaches to appetite suppression. Trends in Pharmacological Sciences 12, 147-157.

Blundell JE, Burley VJ \& Peters JC (1991) Dietary fat and human appetite: effects of non-absorbable fat on energy and nutrient intakes. In Obesity: Dietary Factors and Control, pp. 3-13 [DR Romsos, editor]. Tokyo: Japan Science Society Press.

Blundell JE \& Cooling J (2000) Routes to obesity: phenotypes, food choices and activity. British Journal of Nutrition 83, S33-S38.

Blundell JE, Cotton JR, Delargy H, Green S, Greenough A, King NA \& Lawton CL (1995) The fat paradox: fat-induced satiety signals versus high fat overconsumption. International Journal of Obesity 19, 832-835.

Blundell JE \& Hill AJ (1986) Influence of tryptophan on appetite and food selection in man. In Amino Acids in Health and Disease: New Perspectives, pp. 1-14 [S Kaufman, J Fernstrom, $\mathrm{R}$ Roth and S Woo, editors]. UCLA Symposia on Molecular and Cellular Biology, New Series vol. 55. New York: Alan R Liss, Inc.

Blundell JE \& Hill AJ (1987) Nutrition, serotonin and appetite: case study in the evolution of a scientific idea. Appetite $\mathbf{8}$, 183-194.

Blundell JE, Lawton CL, Cotton JR \& Macdiarmid JI (1996) Control of human appetite: implications for the intake of dietary fat. Annual Review of Nutrition 16, 285-319.

Blundell JE \& Macdiarmid JI (1997) Passive overconsumption fat intake and short-term energy balance. Annals of the New York Academy of Science 827, 392-407.

Blundell JE \& Naslund E (1999) Glucagon-like peptide-1, satiety and appetite control (invited commentary). British Journal of Nutrition 81, 259-260.

Blundell JE \& Rogers PJ (1991a) Satiating power of food. In Encyclopedia of Human Biology, vol. 6, pp. 723-733. New York: Academic Press, Inc.

Blundell JE \& Rogers PJ (1991b) Hunger, hedonics, and the control of satiation and satiety. In Chemical Senses, pp. 127-148 [M Friedman, MG Tordoff and M Kare, editors]. Appetite and Nutrition, vol. 4. New York: Marcel Dekker, Inc.

Blundell JE, Rogers PJ \& Hill AJ (1988) Uncoupling sweetness and calories: methodological aspects of laboratory studies on appetite control. Appetite 11, 54-61.

Booth DA (1972) Postabsorptively induced suppression of appetite and the energostatic control of feeding. Physiology and Behavior 9, 199-202.
Booth DA, Chase A \& Campbell AT (1970) Relative effectiveness of protein in the late stages of appetite suppression in man. Physiology and Behavior 5, 1299-1302.

Booth DA, Mather P \& Fuller J (1982) Starch content of ordinary foods associatively conditions human appetite and satiation indexed by intake and eating pleasantness of starch-paired flavours. Appetite 3, 163-184.

Burns AA, Livingstone MBE, Welch RW, Dunne A, Reid CA \& Rowland IR (2001) The effects of yoghurt containing a novel fat emulsion on energy and macronutrient intakes in non-overweight, overweight and obese subjects. International Journal of Obesity 25, 1487-1496.

Burns AA, Livingstone MBE, Welch RW, Dunne A, Robson PJ, Lindmark L, Reid CA, Mullaney U \& Rowland IR (2000) Short-term effects of yoghurt containing a novel fat emulsion on energy and macronutrient intakes in non-obese subjects. International Journal of Obesity and Related Metabolic Disorders 24, 1410-1425.

Butler RN, Davies M, Gehling NJ \& Grant AK (1981) The effect of preloads of amino acid on short-term satiety. American Journal of Clinical Nutrition 34, 2045-2047.

Campfield LA \& Smith FJ (1986) Functional coupling between transient declines in blood glucose and feeding behaviour: temporal relationships. Brain Research Bulletin 17, 427-433.

Carlson NR (1991) Physiology of Behaviour, 5th ed., p. 411. Boston, MA: Allyn \& Bacon.

Cockle SM, Haller J, Kimber S, Dawe RA \& Hindmarch I (2000) The influence of multivitamins on cognitive function and mood in the elderly. Aging \& Men's Health 4, 339-353.

Cordain L, Brand Miller J, Boyd Eaton S, Mann N, Holt SHA \& Speth JD (2000) Plant-animal subsistence ratios and macronutrient energy estimations in worldwide hunter-gatherer diets. American Journal of Clinical Nutrition 71, 682-692.

Cotton JR, Weststrate JA \& Blundell JE (1996) Replacement of dietary fat with sucrose polyester: effects on energy intake and appetite control in nonobese males. American Journal of Clinical Nutrition 63, 891-896.

Crombie N \& Kirk TR (1999) Prevention of weight gain and blood cholesterol reduction after consumption of a high carbohydrate food in men. International Journal of Obesity 23, Suppl. 5, 657.

Cunliffe A, Obeid OA \& Powell-Tuck J (1997) Post-prandial changes in measures of fatigue: effect of a mixed or a pure carbohydrate or pure fat meal. European Journal of Clinical Nutrition 51, 831-838.

Cunliffe A, Obeid OA \& Powell-Tuck J (1998) A placebo controlled investigation of the effects of tryptophan or placebo on subjective and objective measures of fatigue. European Journal of Clinical Nutrition 52, 425-430.

De Graaf C, de Long LS \& Lambers AC (1999) Palatability affects satiation but not satiety. Physiology and Behavior 66, 681-689.

De Graaf C, Hulshof T, Weststrate JA \& Hautvast JG (1996) Nonabsorbable fat (sucrose polyester) and the regulation of energy intake and body weight. American Journal of Physiology 270, R1386-R1393.

Deijen JB, Heemstra ML \& Orlebeke JF (1989) Dietary effects on mood and performance. Journal of Psychiatric Research 23, 275-283.

Deijen JB, Wientjes CJE, Vullinghs HFM, Cloin PA \& Langefeld JJ (1999) Tyrosine improves cognitive performance and reduces blood pressure in cadets after one week of a combat training course. Brain Research Bulletin 48, 203-209.

Dickie NH \& Bender AE (1982) Breakfast and performance in schoolchildren. British Journal of Nutrition 48, 483-496.

Fischer K, Colombani PC, Langhans W \& Wenk C (2001) Cognitive performance and its relation to postprandial metabolic 
changes after different macronutrient ingestion in the morning. British Journal of Nutrition 85, 393-405.

Friedman MI (1991) Metabolic control of calorie intake. In Chemical Senses, pp. 19-38 [MI Friedman, MG Tordoff and MR Kare, editors]. Appetite and Nutrition, vol. 4. New York: Marcel Dekker, Inc.

Fryer JH, Moore NS, Williams HH \& Young CM (1955) A study of the interrelationships of the energy-yielding nutrients, blood glucose levels and subjective appetite in man. Journal of Laboratory and Clinical Medicine 45, 684-696.

Gale CR, Martyn CN \& Cooper C (1996) Cognitive impairment and mortality in a cohort of elderly people. British Medical Journal 312, 608-611.

Green MW \& Rogers PJ (1995) Impaired cognitive functioning during spontaneous dieting. Psychological Medicine 25, $1003-1010$.

Green MW, Rogers PJ, Elliman NA \& Gatenby SJ (1994b) Impairment of cognitive function associated with dieting and high levels of dietary restraint. Physiology and Behavior 55, 447-452.

Green SM, Burley VJ \& Blundell JE (1994a) Effect of fat- and sucrose-containing foods on the size of eating episodes and energy intake in lean males: potential for causing overconsumption. European Journal of Clinical Nutrition 48, $547-555$.

Green SM, Delargy HJ, Joanes D \& Blundell JE (1997) A satiety quotient: a formulation to assess the satiating effect of food Appetite 29, 291-304.

Greenough A, Cole G, Lewis J, Lockton A \& Blundell J (1998) Untangling the effects of hunger, anxiety, and nausea on energy intake during intravenous cholecystokinin octapeptide (CCK-8) infusion. Physiology and Behavior 65, 303-310.

Greenwood CE \& Winocur G (1997) An investigation of glucose effects on learning and memory impairments induced by high fat diets and environmental factors. Brain and Cognition 35, 415-418.

Hassmen P, Blomstrand E, Ekblom B \& Newsholme EA (1994) Branched-chain amino acid supplementation during $30-\mathrm{km}$ competitive run: mood and cognitive performance. Nutrition 10, 405-410.

Heaton KW (1981) Dietary fibre and energy intake. In Regulators of Intestinal Absorption in Obesity, Diabetes and Nutrition, pp. 283-294 [P Berchtold, A Cairella, A Jacobelli and V Silano, editors]. Rome: Societa Editriee Universo.

Hill AJ \& Blundell JE (1986) Macronutrients and satiety: the effects of a high-protein or high-carbohydrate meal on subjective motivation to eat and food preferences. Nutrition and Behaviour 3, 133-144.

Hill AJ \& Blundell JE (1988) Role of amino acids in appetite control in man. In Amino Acid Availability and Brain Function in Health and Disease, pp. 239-248 [G Huether, editor]. Berlin: Springer-Verlag.

Hill AJ \& Blundell JE (1990) Sensitivity of the appetite control system in obese subjects to nutritional and serotoninergic challenges. International Journal of Obesity 14, 219-233.

Hill AJ, Magson LD \& Blundell JE (1984) Hunger and palatability: tracking ratings of subjective experience before, during and after the consumption of preferred and less preferred food. Appetite 5, 361-371.

Hill JO, Seagle HM, Johnson SL, Smith S, Reed GW, Tran ZV, Cooper D, Stone M \& Peters JC (1998) Effects of $14 \mathrm{~d}$ of covert substitution of Olestra for conventional fat on spontaneous food intake. American Journal of Clinical Nutrition 67, $1178-1185$.

Hockey GRJ (1997) Compensatory control in the regulation of human performance under stress and high workload: a cognitive energetical framework. Biological Psychology $\mathbf{4 5}$, $73-93$.

Holt SHA, Brand Miller JC, Perocz P \& Farmakalidis E (1995) A satiety index of common foods. European Journal of Clinical Nutrition 49, 675-690.

Holt SHA, Delargy HJ, Lawton CL \& Blundell JE (1999) The effects of high-carbohydrate vs high-fat breakfasts on feelings of fullness and alertness, and subsequent food intake. International Journal of Food Science and Nutrition 50, 13-28.

Horrocks LA \& Yeo YK (1999) Health benefits of docosahexaenoic acid (DHA). Pharmacological Research 40, 211-225.

Johnson J \& Vickers Z (1992) Factors influencing sensoryspecific satiety. Appetite 19, 15-31.

Kalmijn S, Feskens EJM, Launer LJ \& Kromhout D (1997) Polyunsaturated fatty acids, antioxidants, and cognitive function in very old men. American Journal of Epidemiology 145, 33-41.

Kanarek RB \& Swinney D (1990) Effects of food snacks on cognitive performance in male college students. Appetite 14, $15-27$.

Kaplan RJ, Greenwood CE, Winocur G \& Wolever TMS (2000) Cognitive performance is associated with glucose regulation in healthy elderly persons and can be enhanced with glucose and dietary carbohydrates. American Journal of Clinical Nutrition 72, 825-836.

Kaplan RJ, Greenwood CE, Winocur G \& Wolever TMS (2001) Dietary protein, carbohydrate, and fat enhance memory performance in the healthy elderly. American Journal of Clinical Nutrition 74, 687-693.

Kelly TH, Foltin RW, Rolls BJ \& Fischman MW (1994) Effect of meal macronutrient and energy content on human performance. Appetite 23, 97-111.

Kirk TR, Burkill S \& Cursiter MC (1997) Dietary fat reduction achieved by increasing consumption of a starchy food - an intervention study. European Journal of Clinical Nutrition 51, 455-461.

Kissileff HR (1984) Satiating efficiency and a strategy for conducting food loading experiments. Neurological Biobehavioral Reviews 8, 129-135.

Klassen T, Riedel WJ, Deutz NEP, van Someren A \& van Praag HM (1999) Specificity of the tryptophan depletion method. Psychopharmacology 141, 279-286.

Lang V, Bellisle F, Oppert J-M, Craplet C, Bornet FRJ, Slama G \& Guy-Grand B (1998) Satiating effect of proteins in healthy subjects: a comparison of egg albumin, casein, gelatin, soy protein, pea protein, and wheat glutin. American Journal of Clinical Nutrition 67, 1107-1204.

Lawton CL, Burley VJ, Wales JK \& Blundell JE (1993) Dietary fat and appetite control in obese subjects: weak effects on satiation and satiety. International Journal of Obesity 17, 409-416.

Lawton CL, Delargy HJ, Brockman J, Smith FC \& Blundell JE (2000) The degree of saturation of fatty acids influences postingestive satiety. British Journal of Nutrition 83, 473-482.

Lawton CL, Delargy HJ, Smith FC, Hamilton V \& Blundell JE (1998) A medium-term intervention study on the impact of high- and low-fat snacks varying in sweetness and fat content: large shifts in daily fat intake but good compensation for daily energy intake. British Journal of Nutrition 80, 149-161.

LeNoury JC, Cooling J \& Blundell JE (2000) Different profiles of appetite and sleeping in high-fat and low-fat (behavioural) phenotypes. Appetite 35, 202.

Lethem R \& Orrell M (1997) Antioxidants and dementia. Lancet 349, 1189-1190.

Lieberman HR, Corkin S, Spring BJ, Gowden JH \& Wurtman RJ (1983) Mood, performance and pain sensitivity: changes induced by food constituents. Journal of Psychiatric Research 17, 135-145. 
Lloyd HM, Green MW \& Rogers PJ (1994) Mood and cognitive performance effects of isocaloric lunches differing in fat and carbohydrate content. Physiology and Behavior 56, 51-57.

Lloyd HM, Rogers PJ, Hedderley DI \& Walker AF (1996) Acute effects on mood and cognitive performance of breakfasts differing in fat and carbohydrate content. Appetite 27, 151-164.

Lluch A, Dye L \& Blundell JE (2000) Effects of nutrient manipulations on motivation to eat and performance in high fat and low fat phenotypes. Appetite 35, 202.

Macdiarmid JI, Cade JE \& Blundell JE (1996) High and low fat consumers, their macronutrient intake and body mass index: further analysis of the National Diet and Nutrition Survey of British Adults. European Journal of Clinical Nutrition 50, 505-512.

Macdiarmid JI \& Hetherington MM (1995) Mood modulation by food: an exploration of affect and cravings in 'chocolate addicts'. British Journal of Clinical Psychiatry 34, 129-138.

Markus CR (1999) Relations between stress, food and mood: a role for brain serotonin. PhD Thesis, University of Utrecht.

Markus CR, Panhuysen G, Tuiten A, Koppeschaar H, Fekkes D \& Peters ML (1998) Does carbohydrate-rich, protein-poor food prevent a deterioration of mood and cognitive performance of stress-prone subjects when subjected to a stressful task. Appetite 31, 49-65.

Martin PY \& Benton D (1999) The influence of a glucose drink on a demanding working memory task. Physiology and Behavior 67, 69-74.

Mayer J (1953) Gluostatic mechanism of the regulation of food intake. New England Journal of Medicine 249, 13-16.

Mayer J (1955) Regulation of energy intake and body weight. Annals of the New York Academy of Science 63, 15-43.

Mei N (1985) Intestinal chemosensitivity. Physiology Reviews 65 , 211-237.

Mellinkoff SM, Frankland M, Boyle D \& Greipel M (1956) Relationship between serum amino acid concentration and fluctuations in appetite. Journal of Applied Physiology 8, 535-538.

Miller DL, Catellanos VH, Shide DJ, Peters JC \& Rolls BJ (1998) Effects of fat-free potato chips with and without nutrition labels on fat and energy intakes. American Journal of Clinical Nutrition 68, 282-290.

Milton K (2000) Hunter-gatherer diets - a different perspective. American Journal of Clinical Nutrition 71, 665-667.

Moser L, Plum H \& Bückmann M (1983) Der Einfluß von Dextrose auf die psychophysische Leistungsfähigkeit des Autofahrers. Aktuelle Ernährungsmedizin 7, 7-14.

Muldoon MF, Ryan CM, Matthews KA \& Manuck SB (1997) Serum cholesterol and intellectual performance. Psychosomatic Medicine 59, 382-387.

Novin D, Vanderweele DA \& Rezek M (1973) Hepatic-portal 2-deoxy-D-glucose infusion causes eating: evidence for peripheral glucoreceptors. Science 181, 858-860.

Oomura Y (1988) Chemical and neuronal control of feeding motivation. Physiology and Behavior 44, 555-560.

Owens DS \& Benton D (1994) The impact of raising blood glucose on reaction times. Neuropsychobiology 30, 106-113.

Parker PY \& Benton D (1995) Blood-glucose levels selectively influence memory for word lists dichotically presented to the right ear. Neuropsychologia 33, 843-854.

Ramirez I (1990) What do we mean when we say "palatable food'? Appetite 14, 159-161.

Reid M \& Hammersley R (1995) Effects of carbohydrate intake on subsequent food intake and mood state. Physiology and Behavior 58, 421-427.

Riedel WJ, Klassen T, Deutz NEP, van Someren A \& van Praag HM (1999) Tryptophan depletion in normal volunteers produces selective impairment in memory consolidation. Psychopharmacology 141, 362-369.
Roethlisberger FJ (1997) The Elusive Phenomena: An Autobiographical Account of My Work in the Field of Organized Behavior at the Harvard Business School, p. 47. Cambridge, MA: Division of Research, Graduate School of Business Administration, Harvard University Press.

Rogers PJ (2001) A healthy body, a healthy mind: long term impact of diet on mood and cognitive function. Proceedings of the Nutrition Society 60, 135-143.

Rogers PJ \& Blundell JE (1989) Separating the actions of sweetness and calories: effects of saccharin and carbohydrates on hunger and food intake in human subjects. Physiology and Behavior 45, 1093-1099.

Rogers PJ, Burley VJ, Alikhanizadeh LA \& Blundell JE (1995) Postingestive inhibition of food intake by aspartame: importance of interval between aspartame administration and subsequent eating. Physiology and Behavior 57, 489-493.

Rogers PJ \& Green MW (1993) Dieting, dietary restraint and cognitive performance. British Journal of Clinical Psychiatry 32, 113-116.

Rogers PJ, Keedwell P \& Blundell JE (1991) Further analysis of the short-term inhibition of food intake in humans by the dipeptide L-aspartyl-L-phenylalanine methyl ester (aspartame). Physiology and Behavior 49, 739-743.

Rogers PJ, Pleming HC \& Blundell JE (1990) Aspartame ingested without tasting inhibits hunger and food intake. Physiology and Behavior 47, 1239-1243.

Rogers PJ \& Schutz HG (1992) Influence of palatability on subsequent hunger and food intake: a retrospective replication. Appetite 19, 155-156.

Rolls BJ, Jacobs Laster L \& Summerfelt A (1989) Hunger and food intake following consumption of low-calorie foods. Appetite 13, 115-127.

Rolls BJ, Kim-Harris S, Fischman MW, Foltin RW, Moran TH \& Stoner SA (1988) Food intake in dieters and nondieters after a liquid meal containing medium-chain triglycerides. American Journal of Clinical Nutrition 48, 66-71.

Rolls BJ, Kim-Harris S, Fischman MW, Foltin RW, Moran TH \& Stoner SA (1994) Satiety after preloads with different amounts of fat and carbohydrate: implication for obesity. American Journal of Clinical Nutrition 60, 476-487.

Smith AP, Clark R \& Gallagher J (1999) Breakfast cereal and caffeinated coffee: effects on working memory, attention, mood, and cardiovascular function. Physiology and Behavior 67, 9-17.

Smith AP, Clark RE, Nutt DJ, Haller JG, Hayward S \& Perry K (2000) Vitamin C, mood and cognitive functioning in the elderly. Nutrition and Neuroscience 2, 249-256.

Smith AP \& Kendrick AM (1992) Meals and performance. In Health and Performance, pp. 2-23 [AP Smith and DM Jones, editors]. Handbook of Human Performance, vol. 2. London: Academic Press.

Smith AP, Kendrick A, Maben A \& Salmon J (1994a) Effects of breakfast and caffeine on cognitive performance, mood and cardiovascular functioning. Appetite 22, 39-55.

Smith AP, Kendrick A, Maben A \& Salmon J (1994b) Effects of fat content, weight, and acceptability of the meal on postlunch changes in mood, performance, and cardiovascular function. Physiology and Behavior 55, 417-422.

Smith AP, Leekham S, Ralph A \& McNeill G (1988) The influence of meal composition on post-lunch performance efficiency and mood. Appetite 10, 195-203.

Smith AP, Maben A \& Brockman P (1994c) Effects of evening meals and caffeine on cognitive performance, mood and cardiovascular functioning. Appetite 22, 7-65.

Smith AP \& Miles C (1986a) Acute effects of meals, noise and nightwork. British Journal of Psychiatry 77, $377-387$. 
Smith AP \& Miles C (1986b) Effects of lunch on selective and sustained attention. Neuropsychobiology 16, 117-120.

Smith AP \& Miles C (1986c) The effects of lunch on cognitive vigilance tasks. Ergonomics 29, 1251-1261.

Smith AP \& Rich N (1998) Effects of consumption of snacks on simulated driving. Perceptual and Motor Skills 87, 817-818.

Spring B, Maller O, Wurtman J, Digman L \& Gozolino L (1983) Effects of protein and carbohydrate meals on mood and performance: interactions with sex and age. Journal of Psychiatric Research 17, 155-167.

Strachan MWJ, Deary IJ, Ewing FME \& Frier BM (1997) Is type II diabetes associated with an increased risk of cognitive dysfunction? A critical review of published studies. Diabetes Care 20, 438-445.

Stubbs R (1996) Macronutrients effects on appetite. International Journal of Obesity 19, S11-S19.

Stubbs RJ \& Harbron CG (1995) Isoenergetic substitution of MCT for LCT: effect on energy intake in ad libitum feeding men. International Journal of Obesity 19, Suppl. 2, 28.

Teff KL, Young SN \& Blundell JE (1989) The effect of protein or carbohydrate breakfasts on subsequent plasma amino acid levels, satiety and nutrient selection in normal males. Pharmacology, Biochemistry and Behavior 34, 829-837.

Thompson DA \& Campbell RG (1977) Hunger in humans induced by 2-deoxy-D-glucose: glucoprivic control of taste preference and food intake. Science 198, 1065-1068.

Tournier A \& Louis-Sylvestre J (1991) Effect of the physical state of food on subsequent intake in human subjects. Appetite 16, $17-24$.

Trigazis L, Orttmann A \& Anderson GH (1997) Effect of a cholecystokinin-A receptor blocker on protein-induced food intake suppression in rats. American Journal of Physiology 272, R1826-R1833.

Van Itallie TB (1990) The gluostatic theory 1953-1988: roots and branches. International Journal of Obesity 14, Suppl. 3, 1-10.
Wainwright PE, Huang Y-S, Bulman-Fleming B, Levesque S \& McCutcheon D (1994) The effects of dietary fatty acid composition combined with environmental enrichment on brain and behavior in mice. Behavioural Brain Research 60, 125-136.

Welch I, Saunders K \& Read NW (1985) Effect of ileal and intravenous infusions of fat emulsions on feeding and satiety in human volunteers. Gastro 89, 1293-1297.

Wells AS \& Read NW (1996) Influences of fat, energy and time of day on mood and performance. Physiology and Behavior 59, $1069-1076$.

Wells AS, Read NW \& Craig A (1995) Influences of dietary and intraduodenal lipid on alertness, mood and sustained concentration. British Journal of Nutrition 74, 115-123.

Westerterp-Plantenga MS, Rolland V, Wilson SAJ \& Westerterp KR (1999) Satiety related to $24 \mathrm{~h}$ diet-induced thermogenesis during high protein/carbohydrate $v s$ high fat diets measured in a respiration chamber. European Journal of Clinical Medicine 53, 495-502.

Wing RR, Vazquez JA \& Ryan CM (1995) Cognitive effects of ketogenic weight reducing diets. International Journal of Obesity 19, 811-816.

Wurtman JJ, Brzezinski A, Wurtman RJ \& Laferrere B (1989) Effect of nutrient intake on premenstrual depression. American Journal of Obstetrics and Gynecology 161, 1228-1234.

Wurtman RJ (1982) Nutrients that modify brain function. Scientific American 243, 42-51.

Wurtman RJ, Hefti F \& Melamed E (1981) Precursor control of neurotransmitter synthesis. Pharmacological Reviews 32, $315-335$.

Wurtman RJ \& Wurtman JJ (1989) Carbohydrates and depression. Scientific American 260, 50-57.

Yeomans MR (1996) Palatability and the microstructure of eating in humans: the appetiser effect. Appetite 27, 119-133.

Yeomans MR, Hails NJ \& Nesic JS (1999) Alcohol and the appetiser effect. Behavioral Pharmacology 10, 151-161. 